\title{
A TEXTUAL ANALYSIS OF MEDIA FRAMING OF MASS SHOOTINGS: HOW CHARACTERISTICS SURROUNDING MASS SHOOTINGS ARE FRAMED IN MEN'S AND WOMEN'S MAGAZINES
}

A Thesis
presented to $\begin{gathered}\text { the Faculty of the Graduate School } \\ \text { at the University of Missouri-Columbia } \\ \text { In Partial Fulfillment } \\ \text { of the Requirements for the Degree } \\ \text { Master of Arts } \\ \text { by } \\ \text { HALEY M. PITTO } \\ \text { Dr. Amanda Hinnant, Thesis Supervisor }\end{gathered}$

JULY 2017 
(C) Copyright by Haley M. Pitto 2017

All Rights Reserved 
The undersigned, appointed by the dean of the Graduate School, have examined the thesis entitled

MEDIA FRAMING OF MASS SHOOTINGS:

HOW CHARACTERISTICS SURROUNDING MASS SHOOTINGS ARE FRAMED IN MEN'S AND WOMEN'S MAGAZINES

presented by Haley Pitto,

a candidate for the degree of master of arts,

and hereby certify that, in their opinion, it is worthy of acceptance.

Dr. Amanda Hinnant

Dr. Yong Volz

Professor Jennifer Rowe

Dr. Brian Houston 


\title{
DEDICATIONS
}

\author{
My Mother
}

Mom, you have always been there to encourage, support and congratulate me. You are by far my biggest cheerleader and I couldn't imagine accomplishing this without you. You are the person I can cry to when times are tough and who I can turn to with any and every problem. Never have you turned your back on me or told me I wasn't good enough and you have never let me down. I will never be able to thank you enough for how much you've been there for me and listened to me, not just during this thesis and graduate school, but throughout my entire life. I don't think you know what that means to me. You and I have gone through so much pain together and I hope that one day when I'm - God willing - a rich and successful magazine editor I can take you (and Mocha) to Belize. I hope you know that I would not be the person I am today without you. I love you mom.

\section{My Father}

Dad, you always supported me and encouraged me to pursue my passion for journalism. You gave me the greatest gift that anyone could give another person - you believed in me. I still remember you calling me your "little Lois Lane" whenever I came home and talking about what a great journalist I would be someday. I miss those times and I miss you. I miss our drives around the lake, secret ice cream trips before dinner, and staying up late watching TV together when I was supposed to be asleep. You were taken from mom and I far too soon, but I know that you're with me in spirit and I can only hope that l've made you proud. I love you daddy.

\section{My Best Friend}

Rebecca, we have been best friends since seventh grade and you know me better than I know myself sometimes. You're the one I can relate to like no other and who I can laugh with to no extent. You have always been there for me through the good times and the bad - and you know there have been many bad times - you have always supported me. Thank you for your advice, your constant words of encouragement and your late-night phone calls.

The Seattle Pacific University community

June 5, 2014 will always be remembered. To those affected by the events of that day: you are in my heart and remain in my prayers. My only hope is that this paper will help educate people and encourage conversation about the effects of gun violence and the stigma(s) surrounding mental illness. 


\section{ACKNOWLEDGEMENTS}

I have been so fortunate to have many wonderful professors at the University of Missouri, and without the challenging coursework and the support I was given during my two years here, I would not have been able to complete this degree. I first wish to thank my committee chair, Dr. Amanda Hinnant. I am so grateful for her feedback and support during the research process and for agreeing to chair a thesis committee for someone she had never met before. I would also like to extend thanks to my methodologist, Dr. Yong Volz, and Professor Jennifer Rowe. I am also appreciative of the time Dr. Brian Houston gave serving on my committee.

I would also like to acknowledge and thank my mentor, friend and former journalism professor, Tara Cuslidge-Staiano at San Joaquin Delta College. Tara instilled in me a desire to learn and do more. The moment I enrolled in her class I was hooked. She made me excited to write, report and even to edit. She helped me find my voice by providing me the opportunity to write editorials my first semester her your class and eventually gave me my own column. I have been extremely lucky both during my undergraduate and graduate years to work with such caring and knowledgeable faculty who have pushed me to do more than I thought possible. This thesis is truly a testament to them. 


\section{TABLE OF CONTENTS}

ACKNOWLEDGEMENTS ii

LIST OF TABLES vi vi

ABSTRACT vii

Chapter 1: Introduction $\quad 1$

Chapter 2: Literature Review 3

Defining a Mass Shooting 3

Mother Jones [magazine] definition.

The Gun Violence Archive definition. $\quad 4$

Reddit Mass Shooting Tracker definition. $\quad 5$

$\begin{array}{ll}\text { Media Motivation } & 6\end{array}$

$\begin{array}{ll}\text { News Framing } & 6\end{array}$

$\begin{array}{lr}\text { Frame Changing } & 9\end{array}$

$\begin{array}{lr}\text { Event Salience } & 10\end{array}$

$\begin{array}{ll}\text { Framing Attitudes } & 12\end{array}$

$\begin{array}{lr}\text { Mental Illness. } & 14\end{array}$

$\begin{array}{ll}\text { Race and Ethnicity. } & 17\end{array}$

$\begin{array}{ll}\text { Gender and Sexuality. } & 17\end{array}$

$\begin{array}{ll}\text { Research Questions } & 18\end{array}$

$\begin{array}{ll}\text { Chapter 3: Methodology } & 20\end{array}$

$\begin{array}{ll}\text { Similar Studies } & 21\end{array}$

$\begin{array}{ll}\text { Research Sample } & 22\end{array}$

Esquire's mission statement. $\quad 23$ 
Cosmopolitan's mission statement

GQ's mission statement.

Glamour's mission statement.

Procedure

Chapter 4: Analysis

News Cycle Typical of Mass Shootings

Narrative Depictions.

Individual (Internal) Blame Frame

Mental Health Issues.

Symptoms suffered by the shooter.

Drugs, medication, and counseling.

Identity: gender, sexuality, and masculinity and femininity

Cultural explanations.

Stereotypes: privilege, race, gender, and sexuality.

Societal (External) Blame Frame

Access to firearms.

Military issues.

Profiling the Shooter

Never saw it coming.

Slipping through the cracks.

Recovery and Mourning

Victims of mass shootings.

Survivors of mass shootings. 
Community togetherness.

$\begin{array}{ll}\text { Chapter 5: Discussion and Conclusion } & 64\end{array}$

$\begin{array}{ll}\text { Coverage frames. } & 70\end{array}$

$\begin{array}{ll}\text { Systemic failures. } & 70\end{array}$

$\begin{array}{ll}\text { Blame frames. } & 72\end{array}$

$\begin{array}{ll}\text { Shooter's Identity. } & 72\end{array}$

$\begin{array}{ll}\text { Limitations of the study } & 73\end{array}$

$\begin{array}{ll}\text { Reflexivity } & 73\end{array}$

$\begin{array}{ll}\text { Future Research } & 74\end{array}$

$\begin{array}{ll}\text { References } & 77\end{array}$ 


\section{LIST OF TABLES}

1. Circulation rates and audience demographics per magazine

2. Mother Jones mass shootings and perpetrators from $2012-2017 \ldots \ldots \ldots \ldots \ldots \ldots . .28$

3. Mass shooters' mental health status for $2012-2017$ shootings …..................29

4. Totals for print and online magazine feature articles

5. Narrowed totals for print and online magazine feature articles

6. Frames in men's and women's magazine coverage of mass shootings 34 


\title{
A TEXTUAL ANALYSIS OF MEDIA FRAMING OF MASS SHOOTINGS: HOW CHARACTERISTICS SURROUNDING MASS SHOOTINGS
}

\author{
ARE FRAMED IN MEN'S AND WOMEN'S MAGAZINES \\ Haley Pitto \\ Professor Amanda Hinnant, Thesis Supervisor \\ ABSTRACT
}

The present research attempted to build upon mass shooting studies by analyzing how feature-length magazine articles focusing on these events frame the characteristics surrounding mass shootings in men's and women's health and lifestyle magazines. The researcher conducted a qualitative textual analysis of 24 randomly selected feature-length mass shootings articles in print and online issues of Esquire, Cosmopolitan, GQ and Glamour between January 2012-April 2017. The core findings of this research included how mass shootings almost always fall under one of four frames: individual (internal) blame frames, societal (external) blame frames, profiling the shooter, and recovery and mourning. These articles also presented more complex sub-frames. The sub-frames included: symptoms suffered by the shooter, drugs, medication and counseling, identity, and stereotypes, political and institutional failures, access to firearms, military issues, "never saw it coming," slipping through the cracks, and the victims and survivors of mass shootings as well as community togetherness. 


\section{Chapter 1: Introduction}

Scholars have long been interested in how perceptions of issues and events are shaped by the process of "framing" — that is, the communicative process of highlighting and focusing on certain aspects of reality, (Birkland \& Lawrence, 2009). Framing is essentially unavoidable in the human mind, and in communication for that matter because the world is too dynamic to understand as a whole. When things are changing at a constant rate and mass shootings are a regular occurrence, it becomes easy to form opinions on them due to the continuous media coverage, thus framing becomes unavoidable. An example of this is policy change.

When it comes to policy change of any kind, framing must be focused on specific issues in order to address those problems. School shootings have created a framing struggle similar to terrorist coverage because they can be interpreted in multiple ways. Was the shooter just angry, or did he or she have underlying mental health issues that needed to be addressed? Were there warning signs pointing toward explosive behavior, and could the shooting have been prevented? Did the shooter's ethnicity and or background contribute to what he or she did? Also, was the shooter provoked?

The Columbine High School massacre in April 1999 was the most violent school shooting that happened in the 1990 s and created a need to determine what the underlying cause of school violence, specifically shootings, was 
(Birkland \& Lawrence, 2009). This urge was further perpetuated by media coverage that influenced viewers' perception of events.

(Magazine) consumers often form opinions on important issues such as mental health reform, gun control policies, etc. based off what they read, so it is important to understand the variety of information being presented to the public and the effect this information has on how they view mass shootings. Ultimately, however dependent an audience might be on media discourse, they actively use it to construct meaning. Swidler (1986, p. 273) suggests to think of culture "as a 'tool kit' of symbols, stories, rituals, and worldviews, which people may use in varying configurations to solve different kinds of problems."

Furthermore, magazine coverage of mass shootings has been scarce, and typically limited to news magazines such as Time and Newsweek, as opposed to gender-specific publications (McGinty, Webster, \& Jarlenski, et al., 2014). When considering framing, it is important to bridge this gap between gendered and gender-neural magazines as their frames will likely be different. 


\section{Chapter 2: Literature Review}

\section{Defining a Mass Shooting}

Several scholars have recognized that framing influences the way that viewers perceive events in the media (Birkland \& Lawrence, 2009). The purpose of this research is to use framing theory to examine how race and ethnicity, gender and sexuality, and mental illness enter into the framing of mass shootings. My research will also seek to identify how framing differs depending on different magazine genres; in this instance women's versus men's magazines. The latter topic will be examined more closely in the methods section of my research. However, before we can answer these questions, we must first understand what a mass shooting is. Here, I examine the different definitions of mass shootings.

Currently there are three definitions of a mass shooting, according to an article on The Washington Post website by Ingraham (2016).

Mother Jones [magazine] definition. According to the Mother Jones shooting tracker, a data set which looks at U.S mass shootings from 1982-2016, a shooting becomes a mass shooting if the person kills four or more people (excluding himself or herself); if he or she acts alone; and if the shootings take place in public (work, school, church, etc.).

Limiting mass shootings in this way is helpful because it typically filters out everything except the larger, headline-grabbing incidents that most people would associate as a mass shooting: Columbine, Virginia Tech, Sandy Hook, the 2012 Aurora movie theater shooting, the Pulse nightclub shooting, the Cascade Mall 
shooting in Burlington, Washington. However, this definition excludes many shootings that most reasonable people would consider a mass shooting, such as the man who shot up a movie theater in Lafayette, Louisiana, killing two people and injuring nine others. This case does not fit the Mother Jones definition. Other instances like the killing of three people and shooting of 16 others at Fort Hood in 2014 also isn't included because not enough people died to fit the site's definition. I decided to use the Mother Jones definition of mass shootings for my textual analysis because the texts I was analyzing were magazines and this definition comes from a reputable news magazine.

The Gun Violence Archive definition. When it comes to mass shooting, the difference between life and death can be dependent on the distance to the nearest hospital. Because of this, other organizations base the mass shooting definitions on the number of people injured as opposed to those killed. The Gun Violence Archive, a nonprofit organization that tracks shootings in the United States defines a mass shooting as "four or more shot and/or killed in a single event [incident], at the same general time and location, not including the shooter." Another noticeable difference between definitions from the GVA and Mother Jones is the GVA doesn't care if the shooting happened in a public place or not. However, there are reasons why private shootings, those that don't happen in a public place, are kept separate: gang shootings at exclusive nightclubs, parties and other private events are a common problem. The same goes for abusive men who shoot their families in the privacy of their home. These situations require a different analysis than public shootings, according to Mother Jones' 
Mark Follman, who works on its database. A man who kills his family in the privacy of his home is likely driven by different motivations than one who kills numerous strangers in public.

Reddit Mass Shooting Tracker definition. The argument can be made that no one person can fully understand the toll of gun violence and the way that firearms make it easy to injure or kill people in a short period of time. That is unless the definition of a mass shooting is broadened. Because of this, a group of pro-gun control Redditors began tracking mass shootings as of January 1 , 2013 , and define a mass shooting as four or more people injured, including the shooter; it doesn't matter in what setting the event takes place.

Founded in 2005, Reddit is a social news gathering, web content rating and discussion website, where registered community members can submit content such as text posts or direct links. Content is organized by "subreddits" which include news, science, gaming movies, books, fitness, food, etc. Reddit has grown in popularity over the years and as of 2016, Reddit saw 524 million monthly visitors; 234 million of those were unique users. Reddit is ranked the $11^{\text {th }}$ most-visited website in the U.S. and $25^{\text {th }}$ in the world, according to SimilarWeb, a website that hosts Reddit's analytics.

The Reddit Mass Shooting “Tracker's numbers have now been cited by AP, Reuters, CNN, PBS, NPR, CBS, The Boston Globe, Slate, Salon, VICE, The Economist, The Guardian, and the BBC, as well as 'every [Rupert] Murdoch paper in Australia,"' according to Brock Weller, one of two Redditors who produced the Tracker, in an article by The Trace, titled "How Redditors Are 
Changing the Way the Media Counts Mass Shootings" (Mascia, 2015). Even with these varying definitions, how is media coverage of a mass shooting represented? Media Motivation

To answer this question, researchers looked at two generally held research-based reasons that are relevant to crime and social problems. The first is that most news is driven by gore and violence; the second view is that most news reflects a "herd mentality" (Maguire, Weatherby, \& Mathers, 2002). A herd mentality describes how people are influences by their peers to adopt certain behaviors or ways of thinking about a specific topic. The hypothesis was that the most violent school shootings receive the most attention and the reporting of those shootings reflects a "herd mentality" nature of the media. To determine if this was in fact true the researchers used a content analysis and interpretation of television evening news ( $A B C, C B S$ and NBC news) coverage of crimes.

The study found that crime reports consist of 10-20 percent of all TV news stories. This is because "crime news is relatively cheap and readily accessible," (Chermak, 1994). Also, providing information about crime can be helpful to the public. Additionally, crime news garners viewer interest and spikes ratings because people are interested in the 'gore' factor. However, according to Chermak, there might be negative consequences as a result of this gore coverage such as copycat incidents.

\section{News Framing}

Frame analysis and policy analysis have been developed in sociology and psychology as a way of depicting and engaging the array of arguments and 
counterarguments that surround complex social issues (Gamson \& Lasch, 1983; Schon \& Rein, 1994). Mass media coverage of school shootings is largely influenced by the way news stories are framed. The concept of framing, first introduced by Goffman (1974), was introduced to explain how members of a society could make sense of the world around them; framing also has been refined as an explanation for the media's influence.

In a broader sense, media framing has become a way to present complex social issues in a more accessible and relatable way to the intended audiences (Gans 1979; Scheufele and Tewksbury 2007). A media frame has been defined in literature as "a central organizing idea for news content that supplies context and suggests what the issue is through the use of selection emphasis, exclusion, and elaboration" (Tankard 2001: 100-101). Reese (2007) suggests that media frames may surface as certain aspects of a news story and its "reality" are emphasized. Entman (1993) also states that "to frame is to select some aspects of a perceived reality and make them more salient in communicating text, in such a way as to promote a particular problem definition, causal interpretation, moral evaluation, and/or treatment recommendation" (p. 52).

This discussion of literature focuses on specific examples of research in an effort to identify key issues on the subject of mass shootings in the media and how they relate to viewer perceptions depending on race and ethnicity, gender and sexuality, and mental illness as my research questions will later address. Studies dealing with theories other than media framing have been excluded. Research on this topic may be organized according to studies examining more 
narrow aspects of media framing such as policy change, what is considered newsworthy, how shootings affect public safety, event salience, etc., as well as broader aspects, such as media framing in general. In order to understand what is newsworthy and how the media frames events and characteristics of those events, we must first understand what framing is.

One effective way to analyze how content might contain a specific message or be directed toward a specific audience is through framing theory, a key analytical tool often used in cultural communication research. Goffman (1974) laid the foundation for framing theory with an account of how expectations are used to make sense of everyday situations. Goffman suggested that, when informed by prior experience and knowledge, individuals organize their thoughts and experiences within frames - "schema of interpretation" — which enable them to more easily "locate, perceive, identify and label" the world around them.

A study by Weaver (2007) examined the differences and similarities between second-level agenda setting and framing and between priming and agenda setting. His hypothesis was that there are similarities between secondlevel agenda setting, framing and priming. Data were presented from multiple studies on framing, agenda setting and priming. The study found that there are similarities between framing and second-level agenda setting but the processes are not identical. Both are concerned with how issues are presented in the media and focus on the most important themes/aspects of interest. There were not any notable differences in terms of this research. Framing was found to be more popular than agenda setting and priming. 
Framing is more popular in part to the influence it plays on society and issues concerning public policy. In "Assessing the democratic debate: How the news media frame elite policy discourse" Schnell (2001) sought to examine the way the media frames public policy issues and to what extent other interest groups, such as politicians, influence the framing process. The study focused on gun control comparing the language of politicians and interest groups to actual news coverage from 1988 to 1996 by means of a content analysis of news. The findings were that both parties worked to ensure that their agenda was met. They did this by appealing to different audiences in an attempt to gain their vote and sway them from the other side by presenting the opponent in a negative light.

The media sometimes aided in this process in the structure and tone of the gun control debate, their distribution of framing perspectives and talked about guns as part of a "culture of violence," (Schnell, 2001). However, frames can change over time.

\section{Frame Changing}

Tewksbury, Jones, Peske, Raymond, and Vig looked at how framechanging events evolve over time by examining New York Times articles through a content analysis. The study found that some shootings were covered more extensively than others, but the timing of the articles all had a similar pattern. Coverage usually spiked within the first two to four days after the shooting and then tapered off after a month.

In understanding that frames can change it is also important to consider how framing is related to priming and agenda setting. Scheufele \& Tewksbury 
(2007) conducted a study that looked at how the three models are related and what those relationships tell us about the effects on media. The researchers posted two important questions: Are these three theories related? What is the relation and how can we build off this to further explore audience perceptions of media?" By examining different information from case studies, memos, previous research, etc., the study found that framing, priming and agenda setting need to be further explored to make them useful as building blocks for theory building. How these different models shape audience perceptions in the real world also needs to be tested. In understanding these terms, it is easy to see that event salience is based on the media - they are responsible for what people deem important.

\section{Event Salience}

Object salience has long been the focus of agenda-setting research and framing theory (Chyi \& McCombs, 2004). Often media will reframe an event by emphasizing different aspects of it - consciously or not - to keep it exciting and engaging and to keep people interested. Ex: If there is a news story on a mass school shooting the media might focus on the aftermath one day, the motive the next, gun laws the day after that, and so on. To simplify salience researchers broke it down into five stages, which was dubbed the "issue-attention cycle" (Chyi \& McCombs, 2004).

The purpose of Chyi and McCombs study is to examine how media frame changing contributes to how people view the importance of certain events. Their study looked at the number of news stories published related to the shootings 
and in what way they were framed during the time of the story. It also looked for frame-changing patterns during the time of coverage and the relationship, if any, between space and time frames.

Using a content analysis method to examine media coverage of the Columbine school shootings in the New York Times, it was discovered that the research focused on the relative importance of a public issue or public figure in the media (Chyi \& McCombs, 2004), one of the various frames this research will code for. Other frames will be determined during the textual analysis portion of the research. According to frame-changing theory, when something appears multiple times, it increases its importance to the consumer/viewer. Typically, the importance of an event is based on the amount of media coverage over time. Over time, media often reframe events, focusing on different pieces of the story to keep them fresh.

In another study, Muschert \& Carr (2006), the two researchers sought to apply the framework suggested by Chyi and McCombs in order to determine how it can be applied to frame changing across similar events. They used a content analysis of the New York Times coverage of nine school shootings that took place between 1997 and 2001. Results found that shootings often received the most coverage within the first few days following the event. The Littleton shootings (in Colorado) attracted the most media coverage, appearing in 170 Times articles while the other eight shootings appeared in a total of 120 articles (Muschert \& Carr, 2006). This is partially due to the way the media framed the events in order to keep the story fresh and exciting for audiences to follow. And 
while the school-shooting problem first appeared in the media as an issue of concern only for the community where the shooting occurred, over time this has progressed. Now people all over (those from areas where the shooting didn't happen) follow the events, the aftermath and have opinions on what happened. By keeping the story and the angle fresh the media ensure that they are keeping the subject newsworthy, but this is not the case for all events.

\section{Framing Attitudes}

By looking at the effects of media framing in relation to the victims and the shooter we gain insight into how media influence our attitudes toward school shootings depending on reporting styles (Schildkraut, 2012). Schildkraut hypothesized that school shootings are largely influenced by the way news stories are framed in the media. The study compared coverage from The New York Times and The Post in an attempt to gain insight on how this particular shooting was framed. The Times was chosen for its hard news approach and The Post was chosen for its "infotainment" style as the study dubbed it. The study found that the way a story is framed is based on three things: the suspect, the victims and the event itself (Chemak, 1995). The way that the story is framed is based on how all of these elements are combined. Results found that the most common element when reporting on the Virginia Tech massacre was the shooter was someone to be feared. The media added to this by dubbing him a "murderer," "killer," and other names.

Which shootings get the most coverage often depends on the characteristics surrounding them. These characteristics may involve race and 
ethnicity, gender and sexuality, and mental illness. How these factors enter the overall framing of a mass shooting is important because they often influence how the shooting is covered or what aspect of the shooting is the most focused on.

In a 2009 study by Kwon and Moon the researchers compared U.S. and Korean blogs and news articles about the Virginia Tech shooting to examine if their framing patterns were similar or varied. By using a content analysis method of comparing news articles and blogs they found that there were some consistent framing patterns but the degree of framing was different between the two nations and the two media. Both places had different results because of how the event was presented to viewers and what was stressed the most. In the U.S. the shooter's race was the main topic, and in Korea the story focused on pretty much everything else, as the shooter was of Asian ethnicity and the media did not want to focus on that in an Asian country. Looking back at the differences between how the newspapers framed race in their coverage of the 2007 Virginia Tech shooting, national newspapers focused more on the shooter's race (Holody, Park \& Zhang, 2013). Other studies focused on different characteristics surrounding violence or mass shootings such as gender.

When considering framing attitudes regarding women and mass shootings, studies by Kessler, Sonnega \& Bromet, et al. (1995) consistently show that women are at higher risk of PTSD during their lives than are men. Studies also show that more often than not, women appear to be at greater risk for developing PTSD after mass trauma than are men (Norris, Foster, \& Weisshaar, 2002); (North, Nixon, \& Shariat, et al., 1999). It has also been suggested that 
preexisting mental health problems might lead to gender-related differences in the prevalence of PTSD, (Norris, 2002). Although men and women do not differ in the probability of being diagnosed with a psychological condition, there are gender-related differences in the pattern of disorders that are observed.

Women are more likely to be depressed or to have generalized anxiety disorder during their lifetime; whereas, men are more likely to experience substance abuse problems, conduct disorder and antisocial behavior, (Orsillo, Raja \& Hammond, 2002). How a health issue is framed is an important consideration in understanding media depictions of health issues (Brown, 1995). Furthermore, how the news media construct PTSD is important because media depictions of health issues might influence how individuals think about that issue in general (Clarke, 1992; Ziporyn, 1988) In a study by Stuber, Resnick \& Galea (2006) it was found that women were more likely than men to report symptoms consistent with a PTSD diagnosis and previous experiences of sexual assault, peri-event panic, pre-existing mental health problems, race \& ethnicity, as well as marital status explained the higher prevalence of lifetime PTSD among women. From this research we can conclude that traumatic events, such as mass shootings affect genders differently when it comes to the aftermath of the event.

Mental IIIness. As previously stated, research found that most mass shootings are a result of mental illness. News focuses on mental illness to the detriment of other causes of mass shootings because mental illness is deemed to be an "exciting" or interesting motive for a violent crime (Wahl, 2003). But has 
the view of mental illness become more positive or negative in the media? And how has this influenced attitudes toward certain events?

Research by Follman, Aronsen, and Pan (2014) suggests that mass shootings represent anecdotal distortions of, rather than representations of, the actions of "mentally ill" people as a whole. In fact, there were fewer than 200 mass shootings reported in the United States - defined as crimes in where four or more people were shot — between 1982 and 2012.

Wahl (2003) examined the content of 1999 newspapers compared to 1998 newspapers and found that the ratio of negative to positive stories involving mental illness actually decreased from 1998 to 1999 . However, the negative stories continued to outnumber the positive ones. It was also revealed that "dangerousness" was the most common theme in stories related to mental illness and positive stories about recovery or achievements were few and far between. Those attitudes then influenced public opinion, public policy and news coverage of events relating back to mental illness.

McGinty, Webster, Jarlenski, and Barry (2014) found that the amount of news coverage surrounding recent mass shootings has moved the issue of serious mental illness (SMI) and gun violence to the forefront of the public agenda during several points in the past six years. McGinty et al. (2014) suggested the heightened public attention to the issue may raise public support for gun violence prevention policies (gun control), and might also exacerbate negative attitudes about people with SMI. McGinty et al. (2014) suggested future research should consider how public exposure to violent acts committed by 
persons with SMI in the news media influence public support for improving public mental health services.

In another study, Metzl and MacLeish (2015) found that connections between mental illness and gun violence are less causal and more complex than current U.S. public opinion and legislative action allow. Their findings suggest that neither guns nor people exist in isolation from social or historical influences. Furthermore, the researchers suggest that understanding a person's mental state is vital to understanding his or her actions. Metzl and MacLeish (2015) also found that connections between loaded handguns and alcohol, the mental health effects of gun violence in low-income communities, or the relationships between gun violence and family, social, or socioeconomic networks are only a few of the topics where mental health expertise might go hand-in-hand with community and legislative discourses in order to promote more effective medical and/or moral arguments for gun policies. Finally, the researchers also suggest that the stigma linked to guns and mental illness is complex, multifaceted, and extremely politicized and beneath seemingly straightforward questions of whether certain assailants meet the criteria for a particular mental illness, are ever-changing categories of race, gender, violence, and, diagnosis itself.

Previous research shows that the way a shooting is covered and how the issues surrounding it, such as metal illness, are addressed can create a positive or negative outlook for public opinion surrounding the event. School shootings can incite viewer panic and the roles played by the media, the public themselves, 
and politicians often frames that panic in a way that best supports their interests without caring who is affected one way or the other (Burns \& Crawford, 1999).

Race and Ethnicity. Aside from mental illness, race and ethnicity are important factors to consider when analyzing the framing of a mass shooting. This is because "media images may be seen as representations that contribute to the social construction of race in the United States" (Gray, 1995). For example, if a black shooter is portrayed in a better light than a white shooter - although they committed the same crime - people are going to automatically be more fearful or have more opinions (likely negative) toward the race being portrayed in a more negative manner. McQuail (2000) says that positive and negative representations in media may reflect ideologies and attempt to encode meaning(s) for audience members. Representation of race - good or bad may also may lead to discussion of social class and structure in the United States. This can also be applied to the social class and economic standing of the perpetrator or victim of a violent crime such as a mass shooting. Mass media portrayals construct social reality for individuals and groups. Surette (1992) says our collective view of crime is shaped by entertainment portrayals and that news coverage appeals to voyeurism. Basically, what is portrayed becomes an accepted version of social reality.

Gender and Sexuality. It is also important to consider how gender and sexuality enter the framing of a mass shooting. Men and women both experience anger and are equally susceptible to mental illness or any of the other factors surrounding a mass shooting. However, there is something specific about 
masculinity — maybe its deep ties to irrational pride — that leads some men to experience a perceived injustice as a personal, often excruciating, humiliation that cries out for revenge. Sociologist Michael Kimmel states that school shooters often demonstrate their hegemonic masculinity through violence. "Rampage shooters" were found to have been denied their traditional male status or have their sexuality questioned (Kimmel, 2008; Kimmel \& Mahler, 2003). Kimmel also notes that most of the school rampage shootings have taken place in "red" or conservative states with an emphasis on masculinity and gun culture. Kimmel and Mahler (2003, p. 1449) make the argument that, "[h]omophobia — being constantly threatened and bullied as if you are gay as well as the homophobic desire to make sure that others know that you are a 'real man' — plays a pivotal and understudied role in these school shootings." Furthermore, research shows that when a person's identity is called into question, they are likely to react by over-demonstrating qualities associated with that identity. According to an article called "Definitive Reactions to Masculinity Threat: More Negative Affect Toward Effeminate (but not Masculine) Gay Men" sociologists call this "masculinity threat" (Glick, Gangl, Gibb, Klumpner, Weinberg, 2007).

\section{Research Questions}

Mass shootings are framed numerous ways in the media and their coverage depends on a variety of factors. In understanding that the media frames shootings in a way that best supports their views, it is easier to not get caught up in a "herd mentality" way of thinking and form one's own opinions. Considering the different frames the media applies to mass shootings it becomes 
essential to determine which frames are most evident in gender based magazine coverage of such events. Accordingly, this research attempted to answer the following questions:

Primary research question: What dominant frames emerge from men's and women's magazine coverage of mass shootings and how do they promote a particular problem definition or moral evaluation?

Research question 1a: How do the social issues presented in these magazines (mental illness, identity: gender, sexuality, and masculinity and femininity, stereotypes: privilege, race and sexuality) influence the creation and establishment of the overall frames? 


\section{Chapter 3: Methodology}

The purpose of this study is to understand how race and ethnicity, gender and sexuality, and mental illness enter the framing of mass shootings. The study used a textual analysis of two well-known men's and women's magazines Esquire, GQ, Cosmopolitan, and Glamour. Media coverage of mass shootings, specifically in gender-based magazines, is important because it can influence how consumers view the events and policies surrounding the shootings based on the frames presented. This study considered the characteristics of the shootings pertaining to the victim(s), survivor(s), and the shooter(s).

This study assumed the form of a qualitative textual frame analysis and drew from two methods: Textual analysis (Hall, 1957; Van Dijk, 1991) and constant comparison (Glaser \& Strauss, 1967). Textual analysis allows the researcher to consider underlying meanings and lengthy strategies of all aspects of the analyzed content (Hall, 1975). Frame analysis allows researchers to gather information about how other people make sense of the world (McKee, 2003).

Textual analysis was the best approach for this study because it is aimed at uncovering and analyzing the frames surrounding race and ethnicity, gender

and sexuality, and mental illness in four separate texts, in print and online. To improve validity, the researcher also acknowledges conflicting findings on the success of textual analyses as part of the theoretical triangulation model (Denzin, 1978; Patton, 1999). 


\section{Similar Studies}

In terms of prior research, there have been several relevant studies pertaining to mass shootings that utilized frame analysis to study race and ethnicity, gender and sexuality, and mental illness. Park, Holody and Zhang's (2012) study examined race in media coverage of school shootings. Metzl and MacLeish's (2014) study looked at mental illness, mass shootings, and the politics of American firearms. McGinty, Webster and Barry's (2012) study focused on the effects of news media messages about mass shootings on attitudes toward those with serious mental illness and the public's support for gun control. Kalish and Kimmel's (2009) study examined suicide by mass murder; it consisted of frames such as masculinity, entitlement, and rampage shootings.

However, the previously referenced studies have not analyzed TV genderspecific magazines and the framing of mass shootings presented in those magazines. Likewise, several of these studies used quantitative research as opposed to qualitative. Muschert and Larkin's (2007) study and Holody, Park and Zhang's (2013) study both applied quantitative research methods. The latter's study involved news media coverage of the perpetrator's race using agendasetting and framing perspectives. Unlike this study, Holody, Park and Zhang's (2013) study involved television and newspaper coverage of the shootings and did not extend to (men's and women's) magazine coverage. Their study also focused primarily on the 2007 Virginia Tech shootings; this study purposefully 
excluded texts featuring coverage of those shootings due to the significant research already conducted.

Additionally, this study aimed to examine how frames such as mental illness and social issues like gun control enter the framing of mass shootings, like Metzl and MacLeish's (2014) study. However, unlike Metzl and MacLeish's study, this research expands on the frames that play a role in the shootings and sought to discover how framing varied between magazine genres.

Another similar study conducted by McGinty and Webster (2014) examined how the news messages encompassing mass shootings played into public perception and opinion. Their study also looked at the stigma(s) surrounding those with mental illness regarding mass shootings and public opinion on gun control. However, their study only analyzed people with serious mental illness. This study looked at mental illness overall as it can be argued that all mental illnesses are serious.

Lastly, comparable to this study, Kalish and Kimmel's (2009) study explored frames of masculinity, entitlement, and level of violence committed during the shootings. Their study also considered suicide and the frames of mental illness and revenge as motives for committing mass shootings.

\section{Research Sample}

This sample drew content specifically from the two most popular men's and the two most popular women's magazines: Cosmopolitan (1886 as a literary magazine; 1965 as a women's magazine-present), Esquire (1933-present), Glamour (1939-present), and GQ (1957-present). These magazines were chosen 
because of their dominance in the magazine industry, as seen by the circulation rates in Table 1, and each magazine's listing on the American Society of Magazine Editors National Magazine Award Winners list.

Table 1. Circulation rates and audience demographics per magazine.

\begin{tabular}{|c|c|c|c|c|}
\hline & $G Q$ & Esquire & Cosmopolitan & Glamour \\
\hline $\begin{array}{c}\text { Circulation } \\
\text { rate }\end{array}$ & $\begin{array}{c}413,000 \\
\text { MRI Doublebase 2016; } \\
\text { Omniture 2016; ComScore } \\
2016\end{array}$ & $\begin{array}{l}758,502 \text { total } \\
\text { MRI Spring 2016; } \\
\text { June } 2016 \text { AAM } \\
\text { Statement }\end{array}$ & $\begin{array}{l}\text { 17MM audience } \\
2016 \text { GfK MRI Fall, } \\
\text { print plus digital }\end{array}$ & $\begin{array}{c}\text { 300,063 } \\
\text { NRS Jan-Jun } \\
\text { 2016; ABC } \\
\text { Jan-Jun } 2016 \\
\text { Aug-Oct } 2016\end{array}$ \\
\hline $\begin{array}{c}\text { Median } \\
\text { Age }\end{array}$ & $\begin{array}{c}37.4 \\
\text { MRI Doublebase 2016; } \\
\text { ComScore 2016 }\end{array}$ & $\begin{array}{c}45.9 \\
\text { Base: Adults } 2016 \\
\text { Hearst Magazines }\end{array}$ & $\begin{array}{c}33.5 \\
2016 \text { GfK MRI Fall, } \\
\text { print plus digital }\end{array}$ & $\begin{array}{c}31 \\
\text { Condé Nast } \\
\text { Reader } \\
\text { Survey } 2015\end{array}$ \\
\hline $\begin{array}{l}\text { Median } \\
\text { Household } \\
\text { Income }\end{array}$ & $\begin{array}{c}\$ 76,827 \\
\text { MRI Doublebase 2016; } \\
\text { ComScore 2016 } \\
\end{array}$ & $\begin{array}{c}\$ 97,548 \\
2017 \text { Hearst } \\
\text { Communications } \\
\end{array}$ & $\begin{array}{c}\$ 61,017 \\
2016 \text { GfK MRI Fall, } \\
\text { print plus digital }\end{array}$ & $\begin{array}{l}\$ 67,718 \\
\text { ComScore } \\
\text { Aug } 2016, \\
\end{array}$ \\
\hline Readership & $\begin{array}{c}75 \% \text { male } \\
25 \% \text { female } \\
\text { MRI Doublebase } 2016 ; \\
\text { ComScore } 2016\end{array}$ & $\begin{array}{c}50 \% \text { male } \\
50 \% \text { female } \\
2017 \text { Hearst } \\
\text { Communications }\end{array}$ & $\begin{array}{c}28 \% \text { male } \\
72 \% \text { female } \\
\text { MRI Doublebase } \\
2015\end{array}$ & $\begin{array}{l}29 \% \text { male } \\
71 \% \text { female } \\
2016 \text { Condé } \\
\text { Nast }\end{array}$ \\
\hline
\end{tabular}

Additionally, each magazine was chosen for its potential to reflect both male and female perspectives as referenced by the mission statements pertaining to each:

Esquire's mission statement. According to Esquire's media kit (Hearst Communications, 2017), "Esquire is for men who are ambitious in their lives and determined to shape the world."

Cosmopolitan's mission statement. Cosmopolitan's media kit (Hearst Communications, 2017) stated:

Always absolutely real, open and entertaining, Cosmo's coverage dives into everything she cares about - beauty, fashion, work, health, relationships, culture, life.

Our mission is to empower young women to own who they are and be who they want to be, and we're focused on propelling her into her fun, fearless future. No excuses, no bull@\#*\%, no regrets. 
GQ's mission statement. GQ's media kit (Condé Nast, 2017) stated the following:

For more than 50 years, GQ has been the premier men's magazine, providing definitive coverage of style and culture. With its unique and powerful design ... GQ reaches millions of leading men each month. The only publication that speaks to all sides of the male equation, $G Q$ is simply sharper and smarter.

Glamour's mission statement. Glamour's media kit (Condé Nast, 2017), states that it is "The magazine that helps every woman become the "DO" she was born to be. Smart, chic, and all-American, Glamour gives readers exactly what they need to transform every part of their lives: from their closets to their love lives and beyond."

Based on Cosmopolitan's mission statement (Hearst Communications, 2017), it was expected that the women's magazines would focus more on themes of empowerment, change, culture and life. Social issues like parenting (did the perpetrators of the violence grow up in an abusive home?), mental health reform, and gun control issues, and topics of feminism, gender, and survivors rather than victims - were also expected to come up. Glamour alluded to similar aspects when noting that it "gives readers exactly what they need to transform every part of their lives" (Condé Nast, 2017).

It was assumed in part from the mission statements and having previously read multiple issues of $G Q$ and Esquire that the men's magazines would focus on themes opposite the women's magazines: The shooter, their motives, the brutality of the shootings (due to issues concerning masculinity), and gun violence overall. Race, ethnicity and aggression associated with mental illness 
were also expected to arise. GQ specifically states that it is the "only publication that speaks to all sides of the male equation" (Condé Nast, 2017). As a female, this researcher believed the previously mentioned themes to be more masculine than feminine.

The period of the textual analyses involved articles from January 2012April 2017. The researcher chose this period to avoid articles about the Columbine (April 20, 1999) and Virginia Tech (April 16, 2007) shootings as they have been exhaustively covered and the amount of information to collect and analyze would have been overwhelming and perhaps not add anything new to the study.

Additional criteria were made that the study would exclude articles that exclusively featured stories about mass shootings in countries other than the U.S., as the study aimed to look exclusively at U.S. mass shootings. Finally, when compiling the research sample, articles that were classified specifically as feature articles or cover stories by the magazine's table of contents or online tags were collected. The researcher determined that if feature articles were not clearly labeled, articles consisting of 1,000 words or more would meet the criteria.

This search parameter was guided by Santos' (2004) research, which explains that feature articles:

...Offer greater detail, thus making them more appropriate to the study of the (magazine staff's) approach to the significance of further themes. Furthermore, they are considered more suitable in revealing the modes of sociocultural representation since they concentrate on a particular (place or event) (Santos, 2004). 


\section{Procedure}

Following both Hall (1975) and Altheide's (1996) methods, this research study began with a "long initial soak" in the material. During this time the researcher established an outline of emerging frames, followed by a second or "close reading" of the texts. During the close reading, the researcher added, expanded, refined, collapsed and eliminated the initial frame categories. During the second stage of data collection, the researcher noted all relevant passages and their relation to the preliminary frame categories.

To conduct the framing analysis, the researcher used constant comparative analysis as it offers a way to systematically analyze and re-analyze text (Gale, Heath, Cameron, Rashid, and Redwood, 2013). Additionally, the researcher identified repeated frames or themes using various techniques. Some of these techniques included: Reading numerous magazine articles from the selected magazines pertaining to mass shootings, looking for what was emphasized (or not emphasized) in headlines and subheads, what information was put first or left for later in a story; placement of stories, the assumed source of conflict (race and ethnicity, gender and sexuality, or mental illness), and stylistic clues such as: language choices. Ex: "Gunned down" vs. "accidentally hit by a stray bullet."

Additionally, by process of constant comparison, the researcher compared the passage that was currently being analyzed to other passages that fell under a similar framework and made notes of all evolving, or emerging frames and definitions in that category (Glaser \& Strauss, 1967; Altheide, 1996). After 
rereading the texts, recording relevant passages, and sorting those passages into categories, the researcher re-examined the data and further refined the framing categories as necessary.

Due to the unfortunate circumstances that research institutions have yet to recognize the academic value of gendered health, leisure, and lifestyle magazines, the study's sample was largely dependent on local library holdings in print and online through Zinio at the time of the study. Often, the holdings were incomplete. However, the researcher later came across an application called Texture (which is available for iPhone and iPad). Texture's holdings consisted of magazines dating from January 2012 to present, making the article sample complete and consistent. Unfortunately, Texture's free trial only lasted a week before the $\$ 11.99$ monthly subscription cost kicked in - a small price to pay for the information gathered and data collected.

For shootings that were not covered in the print issues, the researcher searched each magazine's associated website to see if there was any additional information pertaining to the study for mass shootings that were not covered in the print issues during the selected timeframe. At first, online-only articles were gathered as a backup resource if the print articles did not contain enough information. Because online articles are updated more frequently than print issues, there were likely to be more articles on the topic.

Search terms for online articles included the following: Gun control, gun rights, guns, massacre, massacres, mass shooting, mass shootings, mental health, mental illness, shootings, shooting survivor, shooting survivors, shooting 
victim, shooting victims, and searches for the name of each mass shooting that occurred during the selected timeframe according to a Mother Jones database, in addition to the perpetrator's name. Refer to table 2 for more information.

Table 2. Mother Jones mass shootings and perpetrators from 2012-2017.

\begin{tabular}{|c|c|c|c|}
\hline Shooting & Location & Date & Perpetrator \\
\hline $\begin{array}{c}\text { Fort Lauderdale airport } \\
\text { shooting }\end{array}$ & $\begin{array}{c}\text { Fort Lauderdale, } \\
\text { Florida }\end{array}$ & $1 / 6 / 2017$ & Esteban Santiago \\
\hline Cascade Mall shooting & $\begin{array}{l}\text { Burlington, } \\
\text { Washington }\end{array}$ & $9 / 23 / 16$ & Arcan Cetin \\
\hline $\begin{array}{c}\text { Baton Rouge police } \\
\text { shooting }\end{array}$ & $\begin{array}{l}\text { Baton Rouge, } \\
\text { Louisiana }\end{array}$ & $7 / 17 / 16$ & Gavin Long \\
\hline Dallas police shooting & Dallas, Texas & $7 / 7 / 2016$ & Micah Xavier \\
\hline $\begin{array}{l}\text { Orlando nightclub } \\
\text { massacre }\end{array}$ & Orlando, Florida & $6 / 12 / 2016$ & Omar Mateen \\
\hline $\begin{array}{l}\text { Excel Industries mass } \\
\text { shooting }\end{array}$ & Hesston, Kansas & $2 / 25 / 2016$ & Cedric L. Ford \\
\hline $\begin{array}{l}\text { Kalamazoo shooting } \\
\text { spree }\end{array}$ & $\begin{array}{c}\text { Kalamazoo County, } \\
\text { Michigan }\end{array}$ & $2 / 20 / 2016$ & Jason B. Dalton \\
\hline $\begin{array}{c}\text { San Bernardino mass } \\
\text { shooting }\end{array}$ & $\begin{array}{c}\text { San Bernardino, } \\
\text { California }\end{array}$ & $12 / 2 / 2015$ & $\begin{array}{c}\text { Syed Rizwan Farook and } \\
\text { Tashfeen Malik }\end{array}$ \\
\hline Planned Parenthood clinic & $\begin{array}{c}\text { Colorado Springs, } \\
\text { Colorado }\end{array}$ & $11 / 27 / 2015$ & Robert Lewis Dear \\
\hline $\begin{array}{c}\text { Colorado Springs shooting } \\
\text { rampage }\end{array}$ & $\begin{array}{c}\text { Colorado Springs, } \\
\text { Colorado }\end{array}$ & $10 / 31 / 2015$ & Noah Harpham \\
\hline $\begin{array}{l}\text { Umpqua Community } \\
\text { College shooting }\end{array}$ & Roseburg, Oregon & $10 / 1 / 2015$ & Chris Harper Mercer \\
\hline $\begin{array}{l}\text { Chattanooga military } \\
\text { recruitment center }\end{array}$ & $\begin{array}{c}\text { Chattanooga, } \\
\text { Tennessee }\end{array}$ & $7 / 16 / 2015$ & $\begin{array}{c}\text { Mohammod Youssuf } \\
\text { Abdulazeez }\end{array}$ \\
\hline $\begin{array}{c}\text { Charleston Church } \\
\text { shooting }\end{array}$ & $\begin{array}{c}\text { Charleston, South } \\
\text { Carolina }\end{array}$ & $6 / 17 / 2015$ & Dylann Storm Roof \\
\hline $\begin{array}{c}\text { Trestle Trail bridge } \\
\text { shooting }\end{array}$ & Menasha, Wisconsin & $6 / 11 / 2015$ & Sergio Valencia del Toro \\
\hline $\begin{array}{l}\text { Marysville-Pilchuck High } \\
\text { School shooting }\end{array}$ & Marysville, Washington & $10 / 24 / 2014$ & Jaylen Fryberg \\
\hline Isla Vista mass murder & $\begin{array}{c}\text { Santa Barbara, } \\
\text { California }\end{array}$ & $5 / 23 / 2014$ & Elliot Rodger \\
\hline Fort Hood shooting 2 & Fort Hood, Texas & $4 / 3 / 2014$ & Ivan Lopez \\
\hline Alturas tribal shooting & Alturas, California & $2 / 20 / 2014$ & Cherie Lash Rhoades \\
\hline $\begin{array}{c}\text { Washington Navy Yard } \\
\text { shooting }\end{array}$ & Washington, D.C. & $9 / 16 / 2013$ & Aaron Alexis \\
\hline $\begin{array}{c}\text { Hialeah apartment } \\
\text { shooting }\end{array}$ & Hialeah, Florida & $7 / 26 / 2013$ & Pedro Vargas \\
\hline Santa Monica rampage & $\begin{array}{c}\text { Santa Monica, } \\
\text { California }\end{array}$ & $6 / 7 / 2013$ & John Zawahri \\
\hline $\begin{array}{c}\text { Pinewood Village } \\
\text { Apartment shooting }\end{array}$ & $\begin{array}{l}\text { Federal Way, } \\
\text { Washington }\end{array}$ & $4 / 21 / 2013$ & Dennis Clark III \\
\hline Mohawk Valley shootings & $\begin{array}{c}\text { Herkimer County, New } \\
\text { York }\end{array}$ & $3 / 13 / 2013$ & Kurt Myers \\
\hline Newtown school shooting & Newtown, Connecticut & $12 / 14 / 2012$ & Adam Lanza \\
\hline
\end{tabular}




\begin{tabular}{cccc}
\hline $\begin{array}{c}\text { Accent Signage Systems } \\
\text { shooting }\end{array}$ & $\begin{array}{c}\text { Minneapolis, } \\
\text { Minnesota }\end{array}$ & $9 / 27 / 2012$ & Andrew Engeldeinger \\
\hline Sikh Temple shooting & Oak Creek, Wisconsin & $8 / 5 / 2012$ & Wade Michael Page \\
\hline Aurora theater shooting & Aurora, Colorado & $7 / 20 / 2012$ & James Holmes \\
\hline Seattle café shooting & Seattle, Washington & $5 / 20 / 2012$ & lan Stawicki \\
\hline Oikos University killings & Oakland, California & $4 / 2 / 2012$ & One L. Goh \\
\hline $\begin{array}{c}\text { Su Jung Health Sauna } \\
\text { shooting }\end{array}$ & Norcross, Georgia & $2 / 22 / 2012$ & Jeong Soo Paek \\
\hline
\end{tabular}

Refer to table 3 for information on the shooter's mental health status

before or during the shooting. This information comes from the Mother Jones

database of U.S. mass shootings between 1982-20171.

Table 3. Mass shooters' mental health status for $2012-2017$ shootings.

\begin{tabular}{|c|c|c|}
\hline $\begin{array}{l}\text { Shooter and } \\
\text { shooting name }\end{array}$ & $\begin{array}{l}\text { Prior signs of possible } \\
\text { mental illness }\end{array}$ & $\begin{array}{c}\text { Mental health status before or during the } \\
\text { shooting }\end{array}$ \\
\hline $\begin{array}{l}\text { Esteban Santiago; } \\
\text { Fort Lauderdale } \\
\text { Airport Shooting }\end{array}$ & Yes & $\begin{array}{c}\text { Santiago had gone to a FBI office in Anchorage } \\
\text { and complained that his mind was being } \\
\text { controlled by the CIA. }\end{array}$ \\
\hline $\begin{array}{l}\text { Arcan Cetin; } \\
\text { Cascade Mall } \\
\text { shooting }\end{array}$ & Yes & $\begin{array}{c}\text { According to the Cetin's stepfather he had } \\
\text { "mental health issues"; court records showed he } \\
\text { suffered from anxiety and depression. }\end{array}$ \\
\hline $\begin{array}{l}\text { Gavin Long; Baton } \\
\text { Rouge police } \\
\text { shooting }\end{array}$ & Yes & Unclear \\
\hline $\begin{array}{l}\text { Micah Xavier } \\
\text { Johnson; Dallas } \\
\text { police shooting }\end{array}$ & Unclear & Unclear \\
\hline $\begin{array}{l}\text { Omar Mateen; } \\
\text { Orlando nightclub } \\
\text { massacre }\end{array}$ & Unclear & Unclear \\
\hline $\begin{array}{l}\text { Cedric L. Ford; } \\
\text { Excel industries } \\
\text { mass shooting }\end{array}$ & Unclear & Unclear \\
\hline $\begin{array}{l}\text { Jason B. Dalton; } \\
\text { Kalamazoo shooting } \\
\text { spree }\end{array}$ & Unclear & Unclear \\
\hline $\begin{array}{l}\text { Syed Rizwan Farook } \\
\text { and Tashfeen Malik; } \\
\text { San Bernardino } \\
\text { mass shooting }\end{array}$ & Unclear & Unclear \\
\hline $\begin{array}{l}\text { Robert Lewis Dear; } \\
\text { Planned Parenthood } \\
\text { clinic }\end{array}$ & Unclear & $\begin{array}{c}\text { The judge in the case has not publicly released } \\
\text { Dear's medical and mental health records. As of } \\
\text { April 5, 2016, Dear was undergoing a } \\
\text { competency evaluation. Dear had a history of } \\
\text { disputes with his relatives and neighbors. At a } \\
\text { hearing in December } 2015 \text {, he said, "I am a } \\
\text { warrior for the babies." }\end{array}$ \\
\hline
\end{tabular}

1 Since this database is an ongoing project, the information in the following table is likely to change. Refer to the Mother Jones database for the most current information. 


\begin{tabular}{|c|c|c|}
\hline $\begin{array}{l}\text { Noah Harpham; } \\
\text { Colorado Springs } \\
\text { shooting rampage }\end{array}$ & Unclear & $\begin{array}{c}\text { Prior to the rampage, Harpham wrote an } \\
\text { "incoherent" blog and rambled "nonsensically" in } \\
\text { a YouTube video about mind control techniques } \\
\text { and God, according to the Denver Post. He had } \\
\text { a history of drug and alcohol abuse. }\end{array}$ \\
\hline $\begin{array}{l}\text { Chris Harper } \\
\text { Mercer; Umpqua } \\
\text { Community College } \\
\text { shooting }\end{array}$ & Unclear & $\begin{array}{l}\text { Harper-Mercer's mother said in multiple online } \\
\text { postings that he had Asperger's syndrome. } \\
\text { Harper-Mercer graduated from the Switzer } \\
\text { Learning Center, a school for students with } \\
\text { special needs, emotional difficulties, autism and } \\
\text { Asperger's syndrome. }\end{array}$ \\
\hline $\begin{array}{l}\text { Mohammod Youssuf } \\
\text { Abdulazeez; } \\
\text { Chattanooga military } \\
\text { recruitment center }\end{array}$ & Unclear & $\begin{array}{c}\text { Abdulazeez "had suffered for years from } \\
\text { depression and possibly from bipolar disorder," } \\
\text { according to a representative of the family. (NYT, } \\
\text { July } 202015)\end{array}$ \\
\hline $\begin{array}{l}\text { Dylann Storm Roof; } \\
\text { Charleston Church } \\
\text { Shooting } \\
\end{array}$ & Unknown & Not listed \\
\hline $\begin{array}{l}\text { Sergio Valencia del } \\
\text { Toro; Trestle Trail } \\
\text { bridge shooting }\end{array}$ & Yes & $\begin{array}{l}\text { While serving in the Air Force, he went to an } \\
\text { emergency walk-in clinic because of concerns } \\
\text { over his mood swings, and had either sought or } \\
\text { been ordered to behavioral health interventions, } \\
\text { according to Fox } 6 \text { Now. In a } 2014 \text { risk } \\
\text { assessment with a psychologist at an outpatient } \\
\text { clinic in Appleton, Valencia del Toro recalled } \\
\text { thinking previously: "If I'm gonna take myself out, } \\
\text { I might as well take other people with me." The } \\
\text { police report obtained by Fox } 6 \text { says that } \\
\text { Valencia del Toro had a history of depression, } \\
\text { suicidal and occassionally homicidal thoughts, } \\
\text { and alcoholism. He was intoxicated on the day of } \\
\text { the shooting. }\end{array}$ \\
\hline $\begin{array}{l}\text { Jaylen Fryberg; } \\
\text { Marysville-Pilchuck } \\
\text { High School } \\
\text { shooting }\end{array}$ & Unclear & $\begin{array}{c}\text { Fryberg was well-liked and allegedly happy, but } \\
\text { was also upset about a girl and had posted } \\
\text { emotional social media messages. No definitive } \\
\text { signs of mental health problem }\end{array}$ \\
\hline $\begin{array}{l}\text { Elliot Rodger; Isla } \\
\text { Vista mass murder }\end{array}$ & Yes & $\begin{array}{l}\text { Rodger was never hospitalized due to mental } \\
\text { illness, but had a long history of mental health } \\
\text { issues dating back to his childhood, and received } \\
\text { treatment from multiple counselors leading up to } \\
\text { his rampage. According to The Independent, } \\
\text { Rodger had considered suicide but had no } \\
\text { history of violence. Just before his rampage, he } \\
\text { sent a 137-page manifesto to multiple people. }\end{array}$ \\
\hline $\begin{array}{l}\text { Ivan Lopez; Fort } \\
\text { Hood shooting } 2\end{array}$ & Unclear & $\begin{array}{l}\text { Lopez "had a long history of troubling behavior," } \\
\text { according to the Washington Post, including a } \\
\text { history of deceiving others, problems in his } \\
\text { personal life, and financial difficulties. However, } \\
\text { officials found that Lopez exhibited no signals } \\
\text { that he could be violent. In the year leading up to } \\
\text { the attack, he sought treatment for medical and } \\
\text { behavioral health ailments. }\end{array}$ \\
\hline $\begin{array}{l}\text { Cherie Lash } \\
\text { Rhoades; Alturas } \\
\text { tribal shooting }\end{array}$ & Unknown & Not listed \\
\hline $\begin{array}{l}\text { Aaron Alexis; } \\
\text { Washington Navy } \\
\text { Yard shooting }\end{array}$ & Yes & $\begin{array}{c}\text { Had told Rhode Island police the prior month that } \\
\text { he'd "heard voices"; had been undergoing } \\
\text { mental health treatment with Veterans Affairs } \\
\text { since August } 2013 \text {. }\end{array}$ \\
\hline $\begin{array}{l}\text { Pedro Vargas; } \\
\text { Hialeah apartment } \\
\text { shooting } \\
\end{array}$ & Unclear & $\begin{array}{c}\text { His mother told authorities her son had been } \\
\text { acting strangely and needed a psychiatric } \\
\text { evaluation. }\end{array}$ \\
\hline
\end{tabular}




\begin{tabular}{|c|c|c|}
\hline $\begin{array}{l}\text { John Zawahri; Santa } \\
\text { Monica rampage }\end{array}$ & Yes & $\begin{array}{l}\text { He was known as a solitary teen who regularly } \\
\text { ditched class and had an interest in assault } \\
\text { weapons; he had been admitted to UCLA's } \\
\text { psychiatric ward for a brief period. }\end{array}$ \\
\hline $\begin{array}{l}\text { Dennis Clark III,; } \\
\text { Pinewood Village } \\
\text { Apartment shooting }\end{array}$ & No & Not listed \\
\hline $\begin{array}{l}\text { Kurt Myers; Mohawk } \\
\text { Valley shootings }\end{array}$ & No & Not listed \\
\hline $\begin{array}{l}\text { Adam Lanza; } \\
\text { Newtown school } \\
\text { shooting }\end{array}$ & Yes & $\begin{array}{l}\text { Lanza had a history of serious mental health } \\
\text { problems that were known to his family and } \\
\text { others, as detailed in a post-massacre } \\
\text { investigation by Connecticut authorities. }\end{array}$ \\
\hline $\begin{array}{l}\text { Andrew Engeldinger; } \\
\text { Accent Signage } \\
\text { Systems shooting }\end{array}$ & Yes & $\begin{array}{c}\text { His family worried about his "paranoia and } \\
\text { delusions" for at least two years prior, and tried } \\
\text { to get him to seek treatment. }\end{array}$ \\
\hline $\begin{array}{l}\text { Wade Michael Page; } \\
\text { Sikh temple shooting }\end{array}$ & Yes & $\begin{array}{c}\text { His Army friends once broke into his apartment, } \\
\text { fearing he'd commit suicide in the '90s. A } \\
\text { psychiatric nurse who lived downstairs from } \\
\text { Page said it was "obvious" he had a mental } \\
\text { illness. }\end{array}$ \\
\hline $\begin{array}{l}\text { James Holmes; } \\
\text { Aurora theater } \\
\text { shooting }\end{array}$ & Yes & $\begin{array}{c}\text { He saw at least three mental health } \\
\text { professionals before dropping out of his } \\
\text { university. }\end{array}$ \\
\hline $\begin{array}{l}\text { Ian Stawicki; Seattle } \\
\text { cafe shooting }\end{array}$ & Yes & His family said he was mentally ill \\
\hline $\begin{array}{l}\text { One L. Goh; Oikos } \\
\text { University killings }\end{array}$ & Yes & $\begin{array}{l}\text { A former instructor at Oikos described him as } \\
\text { "mentally unstable" and "paranoid." }\end{array}$ \\
\hline $\begin{array}{l}\text { Jeong Soo Paek; Su } \\
\text { Jung Health Sauna } \\
\text { shooting }^{2}\end{array}$ & Yes & $\begin{array}{l}\text { His sister worried about his homicidal } \\
\text { tendencies; she said his mental health had been } \\
\text { deteriorating and that he had threatened to } \\
\text { commit suicide with his gun. }\end{array}$ \\
\hline
\end{tabular}

When considering the frames surrounding mass shootings, the researcher looked for problems within the frames and a solution to those problems. For example: What meaning(s) did the frames put forth or was there a frame that appeared more important? Is there a frame that was often downplayed? The researcher then explained the underlying assumptions of the frames discovered. (A) What do these frames imply that is important? (Ex: gun control, mental illness reform, etc.). (B) What do they take for granted? (Ex: if gun laws are more restrictive, will it will mean less shootings). (C) What do these frames exclude

2 The verbiage for the shootings in Table 3 came directly from the Mother Jones database. 
from discussion? (D) What worldviews or tacit theories about what matters are these frames reinforcing? (E) Would different frames lead to a better society?

The total number of feature articles per magazine per genre, in print and online are listed in Table 4.

Table 4. Totals for print and online magazine feature articles.

\begin{tabular}{|c|c|c|c|c|c|c|}
\hline $\begin{array}{c}\text { Name of } \\
\text { magazine }\end{array}$ & Print only & Online only & $\begin{array}{l}\text { Print only } \\
\text { grand total }\end{array}$ & $\begin{array}{l}\text { Online only } \\
\text { grand total }\end{array}$ & $\begin{array}{l}\text { Print + } \\
\text { online }\end{array}$ & $\begin{array}{c}\text { Final total } \\
\text { of all } \\
\text { articles }\end{array}$ \\
\hline Cosmopolitan & 3 & 21 & & & & \\
\hline Glamour & 4 & 9 & 7 & 30 & 37 & 69 \\
\hline $\begin{array}{c}\text { Esquire } \\
\qquad G Q\end{array}$ & 5 & $\begin{array}{l}17 \\
6\end{array}$ & 9 & 23 & 32 & \\
\hline
\end{tabular}

After arriving at the total number of articles for each, a sample randomizer tool found on randomizer.org was then used to narrow the sample size further. Instead of analyzing all 69 articles, the researcher opted to only analyze the articles that were feature length and thus offered further context and details. The excluded articles were short and offered little insight on the shootings. See Table 5 for reference.

Table 5. Narrowed totals for print and online magazine feature articles.

\begin{tabular}{cccc|c}
\hline $\begin{array}{c}\text { Name of } \\
\text { magazine }\end{array}$ & Feature articles & Online only & Print only & $\begin{array}{c}\text { Total feature } \\
\text { articles to } \\
\text { analyze }\end{array}$ \\
\hline Cosmopolitan & 6 & 3 & 3 & \\
Glamour & 6 & 3 & 3 & 24 \\
Esquire & 6 & 3 & 3 & \\
GQ & 6 & 3 & 3 & \\
\hline
\end{tabular}

This total sample of 24 feature articles then underwent the process of textual analysis detailed above. 


\section{Chapter 4: Analysis}

The findings section answers the previously posed research questions in numerical order. First, the typical news cycle of mass shootings regarding their coverage is briefly outlined. Next, the research questions are restated before detailing the frames that reoccur in magazines' mass shooting coverage. Later in this section, but primarily in the discussion section, the factors that influence these frames, as well as framing patterns will be explored in further detail. Instead of organizing the findings by magazine, they will be organized by frame, as some of the frames are common to more than one mass shooting.

Due to the method(s) of this research, the researcher did not include codes or previously set frames during the analysis phase. Instead, the researcher read each text multiple times and identified key frames and subframes as seen in Table 6. Main frames included the following: Individual (internal) blame frames, societal (external) blame frames, profiling the shooter, and recovery and mourning. Each of these frames are expanded on below. 
Table 6. Frames present in men's and women's magazine coverage of mass shootings.

\begin{tabular}{cc}
\hline Main Frames & Sub-frame(s) \\
\hline Individual (internal) blame frames & Mental Health issues \\
Symptoms Suffered by the Shooter & Drugs, medication, and counseling \\
& \\
Identity: gender, sexuality, and \\
masculinity and femininity \\
Cultural Explanations \\
Stereotypes: Privilege, race, and \\
sexuality
\end{tabular}

\section{News Cycle Typical of Mass Shootings}

To understand research question number one - What dominant frames emerge from men's and women's magazine coverage of mass shootings? - we must first understand the typical mass shooting news cycle. By understanding the news cycle, we can determine what frames emerge as the cycle progresses over time. Most online (men's and women's) magazines' mass shooting coverage - especially in the early stages - follows the standard breaking news cycle. Typically, the first 24 hours are solely dedicated to reporting verified, emerging details. However, mistakes are made. For example: Esquire originally reported that multiple individuals carried out the Washington Navy Yard Shooting (Laskas, 2013); this was not the case.

Magazine websites, often alternate between news stories the outlet 
already reported, and follow-up stories with additional details. This can mean minutes, hours, even days, before a clear picture of what happened can form. As more details emerge, reporters begin searching for a motive. Typically, this happens on the second day of coverage as law enforcement officials continue to conduct their investigation, as shown by a story on mass shooting survivors in Glamour (Brody, 2016). Rarely is there "editorializing" or speculation about the shooting in the earliest hours of coverage. So, what frames emerge from the coverage of these shootings after going through the typical news cycle?

Narrative Depictions. A smaller subset of the news frames category, several of the magazine articles analyzed opted to frame the shooting in a narrative manner. The events of the shootings are littered with descriptive words and actions, that attempt to humanize the situation and the people involved. This is notable given the country's cultural obsession with violence and bloodshed.

A Cosmopolitan article by Abigail Pesta about mass shooting survivors made a historical reference to the Northern Illinois University Shooting ${ }^{3}$. The article contained descriptions such as:

The shooter, a graduate of the school named Steven Kazmierczak, sprayed shotgun pellets across the class - 120 students - in Cole Hall. People sprinted toward exits or hid between seats; a few sat frozen. The gunman paused, and some students noticed the opportunity to flee, shouting, "He's reloading!" He resumed firing with the shotgun, then switched to a semiautomatic pistol, marching up and down the room (Pesta, 2013).

3

This shooting took place on February 14, 2008, but was referenced in the March 11, 2014 article - I Survived a Campus Shooting — analyzed during the period of this research. 
The article contains these pieces of narrative dotted with factual details from the case. Another excerpt read:

Ruiz-Santana tasted blood and realized she was lying in a pool of it. "I saw my roommate leaning over me," she says. "She was crying and talking on the phone. Then she was gone." A realization came into focus: She was dying. I don't think I can survive this, she thought. There was no life flashing before her eyes, no rush of memories. Just a vague, confused sense of I'm done (Pesta, 2013).

By including these vivid first-person accounts in each magazines' mass shooting stories, the narrative adds impact and shows that mass shootings are diverse. Is shows that there's not a single cause and shootings can't be curbed by any single policy or reform. Each person reacts differently to a shooting. In the moment, there's the confusion and realization that he or she is in a crisis. After, he or she is conscious that the peace and calm of everyday life has been shattered and they must decide how they're going to pick up the pieces and start moving on. This process of recovery and mourning was one of the main themes in this research. It changes those affected: their beliefs, the way they see the world, and so on.

Cosmopolitan ran a similar article about the Planned Parenthood shooting, written by Jim Rendon. This article contains more actions and details than the previous article. An excerpt read:

Karen was preparing for the day's patients when she heard the loud bangs. Then a shout: "There's an active shooter!" Before she had time to think, she ran out the back door and sprinted through the falling snow to the medical building across the street. She ran into an office there and told the workers to call 911 — she'd left her phone, her coat, everything but the scrubs she was wearing, at Planned Parenthood. She made a quick call to her husband to let him know that she was safe (Rendon, 2016). 
The Planned Parenthood article provides multiple first-person accounts and quotes from witnesses and first responders that day. By presenting narrative depictions in a news story's framing, it offers readers factual knowledge. In turn, this can influence their (the readers') attributions of responsibility, their general attitudes about mass shootings, and their knowledge level pertaining to the crime and policy issues that result from the crime.

GQ's Chris Heath wrote a similar article on the Kalamazoo, Michigan Uber killer. It describes how Jason Dalton shot and severely injured, but did not kill Tiana Carruthers:

The first bullet hit her in her left arm. The second bullet hit her in her right leg. One of the last two bullets broke her other leg, and the other went through her buttocks and lodged in her liver (Heath, 2016).

One of the sentences in the article read "He asked them what they were looking at," she said. "They turned around.... 'Yeah, we're looking at...' That's all the words they got out, because he pulled out the gun and started shooting," read like a narrative fiction story. The article is even titled "The Uber Killer: The Real Story of One Night of Terror." The article provides an extremely detailed description of the night's events with quotes from multiple witnesses, including survivors and members of law enforcement.

This type of article presents an interesting conflict. The narrative descriptions could help some readers to put themselves in the place of those who experienced the shooting. In turn, this could lead to more empathy on the reader's part. However, it is impossible to fully grasp an understanding of these events from an outsider's perspective. Although the writing in these articles 
seemed at time sensationalized, it could also serve as an empathetic outlet to readers.

The research addressed the primary question: What dominant frames emerge from men's and women's magazine coverage of mass shootings? The research also aimed to address the supporting question: (RQ1a) How do the social issues presented in these magazines (mental illness, identity: gender, sexuality, and masculinity and femininity, stereotypes: privilege, race and sexuality) influence the creation and establishment of the overall frames? Within the sample set of 24 articles, a total of four dominant frames emerged: Individual (internal) blame frames, societal (external) blame frames, profiling the shooter, and recovery and mourning. In addition, within these primary frames, several sub-frames were identified. This section of research also analyzed the social issues presented in these magazines (mental illness; identity: gender, sexuality, and masculinity and femininity; stereotypes: privilege, race and sexuality) and the influence these frames could have had on the understandings of mass shootings.

\section{Individual (Internal) Blame Frame}

After the news outlets have reported all the details of the shooting and there is a clear picture of what happened, the media start searching for the "why?" or the shooter's motivation. Mass shootings represent a significant loss of life, so the victims, survivors and consumers of the news alike are extremely invested in learning the reason for the loss of life. These frames include not only the shooter's motivation, but also how society has contributed to the shooter 
committing his or her crime. Refer to table 3 in the methodology for a complete list of mass shootings between 2012-2017 that involved a mentally ill perpetrator.

Mental Health Issues. The shooter's mental state is often the primary focus of a mass shooting investigation, and the coverage, as many of these perpetrators turn out to be mentally unstable individuals or are assumed to have had a history of violence or psychotic episodes. The mental health framework of a mass shooting lies in the shooter's history or displayed signs of mental illness — or as Emma McGinty, the lead author on the study and a professor of health policy at Johns Hopkins University describes it in a Cosmopolitan article — "This is one of the hardest distinctions to make." McGinty then goes on to say:

Anyone who kills someone else in a mass shooting scenario or otherwise is not what we would consider mentally healthy. But that does not mean they have a clinical diagnosis and therefore a treatable mental illness. There could be emotional regulation issues related to anger, for example, which are a separate phenomenon. There could be underlying substance use issues. There could be a whole host of other risk factors for violence going on. In other words, there is no way to perfectly or accurately describe the role that mental illness plays in mass shootings. The person may have been mentally ill or they might not have been (Beck, 2016).

McGinty continues, [And yet] "that link pervades the public psyche." These frames serve to not only provide possible explanations for the shootings, but also to illustrate ways in which these offenders are different from the average person. The magazines for this study turned to mental health more than any other motive as a possible explanation for why these violent crimes occur.

For example, in one article from Cosmopolitan's April 2014 issue by Abigail Pesta, it mentions how "Illinois tightened mental-health checks" after the shooting as the shooter, Steven Kazmierczak, had a known history of mental 
illness (Pesta, 2014). Another example of this is noted in an Esquire article by Tom Junod about how to stop mass shootings. Four sheriff's deputies from the office in Santa Barbara County, California went to Isla Vista shooter Elliot Rodger's apartment to conduct a welfare check after receiving a call from his "social counselor," an acquaintance his family hired to help him fit in. That same counselor received a call from Rodger's mother about a YouTube video Elliot had posted. After watching the video, Mrs. Rodger said that her son was on a path to violence (Junod, 2014). However, instead of calling 911 herself, speaking to her son directly, having him committed or hiring a mental health professional who was equipped to handle Rodger's state of mind in the first place, the chain of events led to the officers leaving after asking only a few questions. A month later, Rodger killed six people, injured 14 others, then shot himself. The "check-thewelfare call became infamous as a missed opportunity" (Junod, 2014).

By going into this level of detail, the article provides a possible explanation for the shootings - a missed opportunity to connect with the shooter and offer help. Furthermore, due to the stigma surrounding mental illness, many people believe talking about the subject is taboo and are less inclined to spread awareness or look for signs of it. The missed opportunity of the Rodger visit just shows what a vicious cycle this problem is.

Symptoms suffered by the shooter. Another mental health frame has to do with what specific mental disorder the shooter suffered from. By understanding the shooter's frame of mind at the time of the event, people might better understand why he or she would commit such a crime. For example, GQ 
ran an article that not only explored the possibility that Kalamazoo Uber shooter, Jason Dalton suffered from mental illness, but provided general information on if he was competent to stand trial (Heath, 2016). Heath poses an interesting point:

When we can't explain something, we often pretend by finding clever words to describe it. Maybe we'll even convince ourselves that we've learned what we needed to so that we can file away the horrific deeds of Jason Dalton, and move on.

That's what we want. That's what we demand. But when it comes to reason and motive, cause and effect, the eternal need for sense and order to triumph over chaos and entropy, we often expect too much. Maybe, more often than we can bear, the one thing we don't want to accept is the one thing we need to: Sometimes the world fractures. It just does (Heath, 2016).

This statement is unsettling because of the uncertainty and mental health stigma it implies. If we can't explain why mass shootings occur, then we often explain them away with mental health issues, which in turn further stigmatizes those with mental health problems and makes it difficult to surmise what causes mass shootings - if we even can.

Drugs, medication, and counseling. Along with mental health, drugs and prescription medications also influence the individual (internal) blame frames. For example, an Esquire article by David Vann about Northern Illinois University shooter Steven Kazmierczak stated that he was on antidepressants prior to the shooting, but stopped taking them:

He also begins weaning himself off the meds. He has to do this. He knows he can. And he does.

He hides this fact for five months. They believe he's still taking the pills. He even reports nonexistent side effects, begins living a double life (Vann, 2013).

This is interesting, not only because it sheds light on a possible motive for the shooting, but acknowledges the fact that no one was aware of what he was doing 
and the possible debate that is likely to ensue over treating mentally ill people with drugs and then making sure they continue to take said drugs. Some outlets even turned to medical experts to determine the possible side effects or dangers of going off medication. In a GQ article, Heath writes "...so over the next few days, all of the following explanations would be offered, often with great conviction, to explain what Jason Dalton had done: mental illness, family breakdown, withdrawal from antidepressants..." (Heath, 2016).

Similarly, according to an Esquire article by Christophe Stuck-Girard, Elliot Rodger had been prescribed an anti-psychotic drug by his psychiatrist but refused to take it. According to the article, "Elliot Rodger had been in therapy since he was eight, but he declined to take an anti-psychotic drug, Risperidone, prescribed by his psychiatrist. Calling his mental health regimen a pointless "waste," he withdrew from therapy after turning 18." Stuck-Girard goes on to say:

Disturbed as he was, and as badly as he needed treatment, Rodger's case illustrates a burgeoning problem with United States mental health: Many young people see psychiatrists and their ilk as little more than authority figures scheming to cram psychostimulants and other mindaltering oblongs down their throats (Stuck-Girard, 2014).

This presents a major problem. Instead of praising the benefits of a process that can help these individuals better themselves, it is implied from the previous quote that those in need of medication or therapy have lost their free will, and they are no longer a self-identifying individual, but rather a "danger that needs to be chemically fixed" (Stuck-Girard, 2014).

Identity: gender, sexuality, and masculinity and femininity. While mass shootings have become more common, research suggests that mass 
shooters experience "masculinity threats" from their peers — and sometimes from an inability to live up to societal expectations associated with masculinity like holding down a steady job, being able to obtain sexual gratification from women, etc. Sometimes these threats are more toxic than others. Men who have their masculinity "threatened" often react in patterned ways: they are more violent, they demand - and often feel entitled to - sexual gratification, and they are more likely to support statements about superiority of males.

Cosmopolitan frames the Isla Vista shooter Elliot Rodger as a prime example of a male who experienced "masculinity threats" and reacted accordingly. In the article by Alex Rees, Rodger hatefully expresses his feelings toward women:

For the last eight years of my life, ever since I've hit puberty, I've been forced to endure an existence of loneliness, rejection, and unfulfilled desires, all because girls have never been attracted to me. Girls gave their affection and sex and love to other men, but never to me (Rees, 2014).

Rodger goes on to say:

I'm 22 years-old (and) I'm still a virgin. I've never even kissed a girl. I've been through college for two-and-a-half years, more than that actually, and I'm still a virgin. It has been very torturous. College is the time when everyone experiences those things such as sex and fun and pleasure, but in those years I've had to rot in loneliness. It's not fair. You girls have never been attracted to me; I don't know why you girls have never been attracted to me, but I will punish you for it. It's an injustice, a crime, because I don't know what you don't see in me. I'm the perfect guy, yet you throw yourselves at all these obnoxious men instead of me, the supreme gentleman. I will punish all of you for it (Rees, 2014).

By including this quote, Cosmopolitan is showing Rodger's "masculinity threat" in detail. He's frustrated that women won't pay attention to him in the way he wants. 
His whole identity is being called into question, and it seems that he believes these women value other men's looks and sexuality more. The fact that they prefer others to him is simply not acceptable. In fact, in his mind, it's a punishable offense.

His narcissism, feelings of superiority, and ego are apparent when he describes himself as "the supreme gentleman." So, does that mean the article frames all men - or men in general — who are rejected sexually or otherwise or have a convoluted image of themselves as violent? No; the article describing Rodger does not suggest that men are somehow inherently more violent than women. However, it does suggest that men are more likely to turn to violence when they view themselves as unable to profess or stake a claim to a masculine gender identity. Because mass shootings are often perpetrated by men, it makes them appear to the public as a gender-based crime, even though that is not always the case (Ex: San Bernardino).

Likewise, it should be noted that femininity also comes into play when considering social-psychological framework. According to a 2015 Cosmopolitan article by Andrea Bartz, the headline reads: "Why It's So Surprising That One of the San Bernardino Shooters Was Female" (Bartz, 2015). This article is accompanied with the subhead: "She doesn't fit the profile, but that doesn't mean our stereotypes are off base." Tashfeen Malik, along with her husband Syed Rizwan Farook, were responsible for the San Bernardino killings. Bartz' article describes Malik as a wife and mother of an infant, a 6-month-old daughter. The article frames the San Bernardino shooting for what it was - a rarity; only 3.8 
percent of active shooter incidents that took place between 2000-2013 involved women, according to an FBI active shooter study (Texas State University and Federal Bureau of Investigation, U.S. Department of Justice, Washington D.C., 2014).

In the same Cosmopolitan article, psychologist Joni Johnson states that until San Bernardino:

Every female mass murderer in recent memory had a history of mental illness. From what we can tell, these women 'snapped.' (This was) not so with many men on the list, who methodically planned their attacks and killed indiscriminately in public (Bartz, 2015).

According to the same Cosmopolitan article, in 99 percent of the cases, the shooter - usually male - acted alone. Since there are comparatively so few female mass killers as Johnson states, it seems that gender identity is used in this case to turn the focus back on males and their masculinity insecurities, such as their inability to attract those of the opposite sex. There is no further acknowledgement of the one percent of mass shootings committed by women.

Cultural explanations. American culture also plays into frame construction (RQ 1a). U.S. culture is discussed as influencing boys and young men to turn to this kind of violence more than anywhere else in the world. This means we need to look not at the shooters' individual characteristics, but rather carefully investigate the sociocultural contexts where aggressive masculinity is produced and applauded.

Stereotypes: privilege, race, gender, and sexuality. From a purely cultural point of view, mass shootings can be understood as an exceptionally violent example of a more general issue regarding the changes in relations 
between men and women, and the historical transformations of gender, race, and class inequalities. The Pulse nightclub shooting is an example of that. LGBTQ+ people around the world have been intimidated and coerced for years. In fact, "terrorizing the LGBTQ+ community has become a redundancy" according to Esquire writer Dave Holmes (Holmes, 2016).

In one article Holmes, details "What it costs to be gay in public." Allegedly, during a recent trip to Miami, the Pulse shooter was confronted with two gay men kissing each other; not only that, but they were kissing in front of his child. This act bothered him so much, a man who already had a known history of violence and was on the FBI watch list, that he went out and bought a gun and was compelled to act out violently toward the gay community (Holmes, 2016). This article, unlike the others, frames this specific shooting in two ways. The Pulse nightclub shooting is framed as a socio psychological explanation and a cultural explanation. Both fall under the individual (internal) blame frame. The shooting was an act of sexual rage (the victims were gay), but it was about more than their sexuality. The Pulse shooting seemed to be a reaction to not following the traditional relationship model of one man and one woman. For Mateen, there was a stereotype in play of what a typical relationship should look like and that's not what he saw, thus he reacted violently.

Regarding race, this research found that many the shootings during the selected timeframe were committed by white males. Examples include Lanza and the Sandy Hook Elementary School shooting, Holmes and the Aurora, Colorado movie theater shooting, and Roof and the Charleston church massacre. 
This list only goes on. However, the articles never outright addressed this fact. This implies that race is not as important to the story as other frames or subframes such as mental health or gun control.

According to a $2016 \mathrm{GQ}$ article, mass shootings are a persistent issue in the U.S., and gun control is by far one of the most important parts of the problem (Paterniti, 2016). However, if we focus solely on guns, we miss out on something even more important: As noted by the previous section, mass shootings are framed as acts of masculinity.

\section{Societal (External) Blame Frame}

While most of the magazine articles seemed to agree that mental health issues were primarily responsible for causing mass shootings, the coverage angle(s) differed. Sometimes, the article focused on specific mental health issues the shooter suffered. Other times, there was a big-picture discussion on how to deal with the widespread issue of mass shootings. In an Esquire article written by Tom Junod, the writer addresses the fact that mass shootings are not unstoppable events, and yet, they keep happening:

The people who carry out these attacks typically do them out of a sense of desperation ... Part of them felt they had to go through with it; part of them felt they didn't want to at all. Part of them looked for encouragement; part of them looked for someone to stop them (Junod, 2014).

He goes on to talk about how people do not just "snap," instead "they all followed a pathway to violence" (Junod, 2014).

Political and institutional failures. Just because someone looks normal and acts normal, does not mean they are in a sound state of mind. According to 
the Esquire article, asking the right questions and paying attention to the displayed warning signs are key to preventing mass shootings. It is suggested that asking questions like "Have you recently acquired a weapon" can go a long way. (Junod, 2014).

This quote seems to support the profiling the shooter frame and the societal (external) blame frame. By asking these questions, certain answers will point to warning signs, so the "never saw it coming" and "slipping through the cracks" sub-frames would be less likely to occur. Furthermore, the societal (external) blame frame, specifically the political and institutional failures subframe come into play. If police — or anyone for that matter — are aware that the person has recently acquired a weapon, they can do something to either get the weapon away from the person or try to pin down their mental health status, if they're on any medications and how involved their parents, friends, or others are in their lives. This quote implies that multiple frames can be addressed with a few questions, thus possibly preventing a future mass shooting.

A Cosmopolitan article by Prachi Gupta details how after the Pulse nightclub shooting, a hashtag \#prayfororlando was created and later changed to \#policychangefororlando with the accompanying \#notonemore. Democratic Congressman Jim Himes spoke out in the Cosmopolitan article after the massacre about gun control policies and what the government should be doing instead of holding a moment of silence: "I will not attend one more "Moment of Silence" on the Floor. Our silence does not honor the victims, it mocks them" (Gupta, 2016). After, Himes took the Senate floor to lead a filibuster for gun 
control. After 15 hours, leaders of the Republican Party agreed to vote on two gun control proposals.

Cosmopolitan's focus on the politicians in this article stood out for several reasons. First, Himes was the only one who spoke up to demand action. Second, the article brought the victims and policy change into focus by suggesting that the government is mocking them by not being more proactive. If more politicians spoke up the way Himes did, or did something - change, enact, or strengthen policies surrounding mental health reform and gun control - that it would reduce the mass shooting epidemic. By remaining silent and not doing anything, these politicians are contributing to the shaping of the societal (external) blame frames. Specifically, they are reinforcing the political and institutional failures sub-frame.

A GQ article by Drew Magary went further. The magazine detailed six steps to take to "win the war on guns" (Magary, 2015). Pressuring the gun makers as opposed to the lawmakers, finding the illegal guns, writing to your local congressperson, asking the President (or presidential candidates at the time of the article), asking for more gun prevention technology, and being prepared to withstand the onslaught of gun rights advocates protesting gun restrictions and regulations.

The GQ article lays out several good points. Currently, there isn't any pressure on gun makers to do anything about gun violence which contributes to the societal (external) blame frame. It seems that it's always up to the politicians or the people themselves. These articles create a discussion about mental illness 
and ways in which government policy change might be able to curb the frequency of mass shootings.

A Cosmopolitan article by Liz Welch stated: "In order to truly save lives, the conversation has to get intimate" (Welch, 2016). Like Esquire, Cosmopolitan explains that people need to ask questions - or more specifically — the right questions when it comes to guns and gun violence. Welch said having an open and honest conversation about guns is important. Is there a gun in the house? Are you comfortable with the gun being there? Who else knows about the gun? Are they OK with it? Are children or young adults in the house? Do they have access to it?

Emily, a 21-year-old college student in Baltimore, says that "most younger people have similar views on issues like sex and birth control so those are generally less controversial topics. But a lot of people my age have different views on guns, so it's something that l'd be less likely to talk about openly (Welch, 2016).

It appears that not talking openly about gun rights, gun safety, and gun access is part of the problem. When people shy away from asking important questions about important issues, it's a lost opportunity. Open dialogue is part of the political and institutional failures sub-frame as well as the profiling the shooter frame. By asking these questions, you can learn a lot about a person from the answers he or she provides.

According to an Esquire article by Jack Holmes, Congress did pass the Mental Health Reform Act of 2016, "which provides funding for expanding access to mental health care and to teach educators about the signs of mental illness" (Holmes, 2016). At the state level — specifically in Connecticut — where Sandy 
Hook took place, the state "passed some of the strictest gun control laws in the nation" (Holmes, 2016), and seven states have passed laws creating universal background checks since Newtown: Washington, Oregon, Nevada, Colorado, New York, Connecticut, and Delaware. Seven states and Washington D.C. have also passed bans on assault rifles (Holmes, 2016). And while these laws are better than nothing, they are insufficient. Chicago, Illinois — which heavily regulates guns - has a major gun problem due in part that it's next door to Indiana. "Of 50,000 illegal guns recovered by Chicago police between 2001 and 2012, 22,000 came from within Illinois. The rest were trafficked in from out of state, including nearly 8,000 from Indiana" (Homles, 2016). So even when policies are changed and the government takes action, access to firearms remains a problem.

Access to firearms. The weapons the shooter used to commit the crime and the way they were acquired is also a large frame of reference for reporting. This frame focuses on whether the guns were acquired legally or not, and if the shooter should have been allowed to legally obtain the weapon. In a Glamour article by Chelsea Stone and Krystin Arneson, the women interviewed FBI agent Ronald Hooper. Hooper said Orlando shooter Mateen purchased "at least two" firearms the week before the shooting and had "active firearm and security guard licenses" (Stone and Arneson, 2016).

Another Glamour article by Krystal Marie Ball and S.E. Cupp mentions how the San Bernardino shooters purchased their four guns legally (Krystal Marie Ball and S.E. Cupp, 2015). Marie Ball said it didn't really matter what 
laws California passed after the San Bernardino shooting "when guns are so easily purchased in nearby states." Gun trafficking is real, and it's a serious problem when considering the political and institutional failures sub-frame regarding access. It doesn't make sense to base policy on one specific incident, and while we don't know what could have prevented San Bernardino — if anything — the fact remains "that eight of the gunmen in 15 recent mass shootings bought guns legally despite criminal records and mental illness" (Krystal Marie Ball and S.E. Cupp, 2015). Therefore, it can be interpreted from this frame that consistently banning those with a documented mental illness or criminal record would have made accessing guns much more difficult for the shooters.

After every mass shooting comes the question: Could it have been prevented? Is there anything anyone could have done to stop the shooter from killing others, and often taking his or her own life? According to a Glamour article by Jillian Kramer "Harper-Mercer, who suffered from a mild form of autism and had more than a dozen guns at his disposal in the home he shared with his mother, targeted Christians in his attack" (Kramer, 2015). Harper-Mercer's mother, Laurel Harper, revealed in online forums that she worried about her son's developmental issues, but was also a fierce defender of gun rights. Laurel wrote that both she and her son suffered from Asperger's syndrome (Kramer, 2015).

There are similarities between the Umpqua Community College shooting Harper-Mercer committed and Adam Lanza's attack on Sandy Hook Elementary 
School. According to a Cosmopolitan article by Kate Storey, Adam Lanza was known to have had a history of mental illness that had long gone unchecked. The families of his victims came forward with lawsuits after the shooting blaming Nancy Lanza's (the shooter's mother) "carelessness and negligence" for leaving a Bushmaster AR-15 rifle unsecured in the house with her son (Storey, 2015). "Nancy Lanza was a known gun enthusiast and owned at least a dozen firearms. She also knew that her son 'showed signs of mental health problems' leading up to the time of the attack. Nancy was also killed" (Storey, 2015). One of the lawsuits claimed that Nancy had allowed her son access to the weapons "despite the fact she knew, or should have known, that his mental and emotional condition made him a danger to others" (Storey, 2015).

Military issues. This is a frame that fits in the access to firearms subframe as shooters with a military background are often prone to mental health issues such as PTSD, among other things, and have access to deadly weapons. In some shootings, such as the Washington Navy Yard shooting and the Sikh Temple shooting, the soldier's life and other issues related to the military become a frame of reference.

Another article by Esquire reporter Cal Fussman details Lieutenant Brian Murphy's account of the Sikh Temple shooting committed by Wade Michael Page:

We later found out that he'd been in the Army. So he understood the paramilitary set of law enforcement. While there's a separation between military and law enforcement, there's still a kindred feeling for doing the same type of job. You wouldn't kill one of your own. He knew exactly who I was. He didn't care at that point. You could see that in his eyes. He didn't care about anything (Fussman, 2012). 
At the time, Murphy didn't know about Page's military background. He just thought Page was shooting the people from the Temple as part of another random mass shooting. Pages' motives were unclear at the time and so was his mindset - so it seemed. However, Murphy later realized that Page knew exactly what he was doing and who he was doing it to; he just didn't care. It seems like it doesn't matter if there's a military or law enforcement connection between a shooter and his victim. He's going to do what he wants to do, and no one is going to get in his way. There's no kindred feelings or brotherhood when it comes to who gets shot and who doesn't. Mass shootings are all different in their own ways and each shooter as unpredictable as the next. The profiling the shooter frame and societal (external) blame frame both come into play with the Sikh Temple shooting. There were signs in Page's past that he was capable of something like this, but he managed to slip through the cracks.

Shootings such as those as the Washington Navy Yard and Sikh Temple shooting often face extra scrutiny because they took place at military or government installations, involved active duty or former soldiers, or the shooter believed he or she was entitled to the gun (and to use it) because of their connection to the military. From an Esquire article by Tom Junod:

It wasn't just the guns. It was how the guns shaped his thinking - how they fed his thinking. They were always there. There were fourteen of them in a locked closet. They were military-grade weapons. There was an M1 rifle. There was a Swedish Mauser. There were Russian SKS's. And there was ammunition, loads of it. It was all just right there, a few feet away, and not just physically. Spiritually. In his memories. One of his earliest memories was of his father sitting on the couch cleaning his guns. He always knew they were readily accessible. But in his mind, they were more than that. His father was a member of the NRA. He believed in the God-given right to bear arms. But what did that mean, God-given, to a boy 
like him? It meant that God wanted him to have a gun. It meant that deep down he was a warrior. It meant that he was born to be something other than what he was (Junod, 2014).

Junod is calling the reader's attention to the fact that guns were a normal part of this young man's life. He was raised with them, and they connected him to his father. The boy didn't see anything wrong with using a gun — even one not registered to him, but rather his father — because he believed it to be his right. Junod seems to be putting the blame (societal blame frame) on the parent who raised his or her child this way and on the parent as an institutional frame that allowed such easy access to these guns, including military-grade weaponry.

Statements like these often lead to reviews and overhauls of security practices at these locations. An Esquire article by Charles P. Pierce regarding the Chattanooga military recruitment center shooting:

Personal safety, personal security has always been a main concern. Chattanooga just brings into (further) light the reality of that concern and what we need to do on a daily basis, said Sgt. 1st Class Timothy Konitzer, a longtime Army recruiter in San Diego (Pierce, 2015).

This passage plays into the establishment of the societal (external) blame frame, specifically the political and institutional failures sub-frame in that the shooting happened at a recruitment center where the security protocols were more lax than they would have been on an actual military base. The two entrances had unmanned gates, and the concrete barriers could be driven around. If the recruitment center was treated like an actual military post in the first place — armed guards present at the entrances and concrete barrier — the shooting may have been prevented. It was only after the shooting occurred did they realize that there should have been a higher level of security. 


\section{Profiling the Shooter}

Profiling the shooter is another dominant frame that emerged from men's and women's magazine coverage of mass shootings. During the process of reporting the full, detailed, and accurate version of the events following a mass shooting, news outlets typically try to find out more about the perpetrator to understand how someone could reach a point where they would commit such a crime.

Never saw it coming. Over the course of the investigation, those who knew or lived near the shooter are often interviewed for their perspective. Usually, they will reveal that they never would have imagined the perpetrator doing something like this. For example, James Block, a neighbor of Uber shooter Jason Dalton, described said in an Esquire article:

When the Daltons first arrived, they kept to themselves, but a couple of years later, after they had a baby boy, they opened up more. Or Jason did, anyway. He was a talker. A ten-minute conversation turned to 40 minutes, easily. He was so sociable. He would never actually let you leave (Heath, 2016).

Like Block's account, these shooters are often described as quiet and polite, but rarely ever troubled or violent. This frame seems to highlight the fact that these events are tragically unexpected and there's rarely — if ever - a way to predict them, or predict who the next shooter will be.

Slipping through the cracks. One of the most widely used phrases regarding a shooter, along with terms like "red flags," is the phrase "slipped through the cracks." Often, the shooting seems like something that should have been noticed or could have been prevented. However, warning signs 
and red flags are often ignored. For example, Isla Vista shooter Elliot Rodger. According to an Esquire article by Luke O'Neil, Rodger was reported to have posted "unsettling" videos to YouTube and a "140-page manifesto now posted online" (O’Neil, 2014). He also sent disturbing videos to family members and joined an online forum called PUAHate.com also known as PickUpArtistHate.com. Rodger wrote in his manifesto that he:

Tried to show it to my parents, to give them some sort dose of reality as to why I am so miserable. They never understood why I am so miserable. They have always had the delusion that everything is going well for me, especially my father. When I sent the link of PUAHate.com to my parents, none of them even bothered to look at the posts on there (O'Neil, 2014).

It's interesting that O'Neil and Esquire chose to quote from the manifesto. Repeating the shooter's reasons for his or her actions seems to take advantage of this form of communication (writing a manifesto) and blame the incident on an uncaring system or disinterested parents who allowed these severely disturbed individuals to continue with their lives until they snapped and caused harm to themselves, others, or both. In a way, it takes the shooter's side by justifying what he or she did because of deeply personal issues only revealed in what he or she left behind. Including quotes from a manifesto or even linking to or uploading the entire document — only further sensationalizes the event in a poor attempt to gain sympathy from the readers. It also preys on readers' curiosity and their need to know why by getting them to read the story if they had not done so already. 


\section{Recovery and Mourning}

The end of a mass shooting's news cycle deals with how the survivors and their families, the community they live in, and society at large go through the grief, mourning, and recovery process. There were several articles in the magazines analyzed that focused on the identities and lives of the victims of these shootings, their families, the survivors and their families, as well as coverage of the victims' funerals. For example, a story from Cosmopolitan written by Megan Friedman, Madison Feller, Maggie Maloney, and Robyn Smith dedicated itself solely to identifying and detailing the lives of the Orlando Nightclub Massacre victims:

(Edward) Sotomayor was the national brand manager at ALandCHUCK.travel, a travel agency catering to the LGBT community, and coordinated themed cruises around the TV show RuPaul's Drag Race, according to the Orlando Sentinel. He recently put together the first-ever gay cruise to Cuba and urged people to not let the fear of homophobia get in their way of traveling the world (Friedman, Feller, Maloney, and Smith, 2016).

Victims of mass shootings. A short anecdote and a few qualities about the victim(s) usually accompany this type of story.

Another example from the same Cosmopolitan article describes a couple who were killed in the Pulse nightclub shooting:

(Juan Ramon) Guerrero and (Christopher Andrew) Leinonen lived together and had been dating for almost two years before they were killed. They will be remembered at a joint funeral. They were honestly so in love. They were soul mates. You can tell by how they looked at each other, Juan's sister Aryam said. It's a little comforting that they died together (Friedman, Feller, Maloney, and Smith, 2016).

Sandy Hook stories also focused largely on funeral stories and the parents' grief due to the extremely young age of the victims. Consider this 
chilling visual from Esquire's John Hendrickson about the Sandy Hook Elementary School shooting:

One father saved his son's bicycle helmet because it still contains a few strands of his long, blonde hair. He hides it in the garage; he plans to keep it forever. Another expresses that, given his son's young age, he knew almost everything he had ever experienced in his short life. But he didn't know what it felt like, or what was going through his son's head, during the final hours, those minutes before he was pumped full of bullets for no reason other than being present for school that day. It is hard to listen to a father reminisce about the good times he had with his deceased boy. It is another thing to listen to a father tell you he wants to know exactly how it felt for his son to be murdered (Hendrickson, 2016).

In this quote, the fathers are trying to be strong and hold themselves together but they can't help but feel guilty. Their children's' lives were cut short and there was nothing they could do to prevent it. They couldn't save them and that chips away at their masculinity and their identity as fathers — protectors. In turn, this creates the individual (internal) blame frame, as well as the recovery and mourning frame. The shooters blame themselves for not being there and now they need to find a way to move past what happened. Keeping reminders of their children is therapeutic, but it's also a punishment because of the guilt and responsibility they feel.

Survivors of mass shootings. However, the media presence in the towns where these shootings took place - and their participation in the grieving process - is not always appreciated because of the intrusive nature. Often reporters are criticized for not giving the victims more privacy during such a difficult time. A Glamour article by Liz Brody detailed the accounts of eight mass shooting survivors, including their experiences with news outlets reporting on the shootings. Chloe Quinn, a then-sophomore at Umpqua 
Community College explains how media overstepped when it came to reporting on the October 2015 shooting:

As we walked out of the science building with our hands on our heads, the press was already there, taking pictures and hunting for people who looked vulnerable, because they wanted a good story. My picture was all over the news. It was incredibly violating. (Brody, 2016).

Detailing the level of media violation (typically television reporters as opposed to print) shows the reader how much more difficult it can be for the survivors and their families to recover and mourn for those lost. When every move - every emotion - is captured on film or camera and nothing is private. It victimizes those people all over again, drags out the recovery process and makes the mourning process even harder to go through. Quinn presenting this level of violation could give pause to reporters covering future mass shootings.

From the same article, survivor Kristina Anderson details her account:

I woke up in the hospital. The news was on, and I instantly recognized myself as the girl in the white shirt being carried out. I thought, How did a photographer get there so fast? Why would someone want to capture the worst day of my life? They never asked my permission. I had a lot of anger because that picture is just everywhere. (Brody, 2016).

Even though the worst day of Anderson's life was displayed for all to see angering her and possibly violating her all over again (recovery and mourning frame) - the compelling visual could have an impact on the political and institutional failures frame for the better.

Despite the media intrusion, family are framed often as playing a role in the survivors' recovery and mourning process. In a Cosmopolitan article by Abigail Pesta, one of the survivors, of the Northern Illinois University shooting, Maria Ruiz-Santana, describes how her "mom held (her) hand and told (her) it 
was okay," and how after the shooting, "her family helped her cope, her parents never leaving her side" (Pesta, 2014). Through the mix of uplifting and depressing stories following a mass shooting, there are often many support stories featuring members of the community gathering to support the survivors, victims, and their families in the wake of the tragedy.

Community togetherness. This sub-frame emerges when the community comes together - in person and online - to support those affected by the shooting. For example, in one article from GQ by Sean Flynn, the article's subhead describes the shooting as "Not (being) about what happened that night but, rather, what happened in the days and weeks and months that followed, as a community - a community of unbreakable young men and women - found it within themselves to forge ahead (Flynn, 2016).

In another instance, the same article references how in response to the Pulse nightclub shooting: "Millions of dollars will be donated, because more people are decent and kind than not" (Flynn, 2016). Two days after that shooting Orlando mayor Buddy Dyer announced the formation of the OneOrlando Fund and thousands of individuals and corporations donated millions of dollars. "It was just an instinctual 'What can I do to help?'” a citizen named Aly Benitez said in the GQ article. The community's knee-jerk reaction was: "I have to do something." By mid-October, the community had raised a quarter million dollars and given out \$200,000 (Flynn, 2016).

In terms of framing, community togetherness can advance the recovery and mourning frame. Helping move past the tragedy by rebuilding, paying 
medical bills, and providing temporary housing for out-of-state friends and family lessens the burden on those who were affected. Furthermore, establishing this kind of support system can help in both the short term and long term.

However, several articles focused on the shootings seemed to dictate that this sense of togetherness and recovery wasn't what it seemed. In a Glamour article by Sarah Wildman and Sarah Robbins several survivors describe what it's like to "move on" from a mass shooting. For Heather Egeland, she said once the news crews pack up and everyone goes home, the survivors (and their families) are left to deal with the aftermath: "We know the trauma lasts for years" (Wildman and Robbins, 2015).

Despite the comfort community togetherness may bring for a community, it's often only temporary comfort for those who experienced the event firsthand. Survivor Amber Gadlin says a lot of the survivors stay connected because they're the only ones who really know what it's like to go through the trauma of a shooting: "We talk all the time — not about what happened, but How are you doing?' It's very helpful. Please, world, do not forget" (Wildman and Robbins, 2015).

The recovery and mourning period following a shooting is different for the survivors, the survivor's friends and families, the victim's friends and families, and the rest of the public. For those directly affected, the recovery and mourning stage could last a lifetime. For everyone else, it lasts for a while and then fades until the next shooting. It's easy to move on when you're not directly affected. This promotes a moral evaluation of how a large group of people react to trauma 
immediately after it happens versus after some time has passed. The problem with community togetherness is in its definition - togetherness - people are there to support one another when they feel they need to do something and when they have, they move on. Togetherness is temporary, and survivors like Gadlin know that. They know they need to be there for one another because eventually they're all they have.

Togetherness is framed not as a long-term solution, but rather an in-themoment reaction to help those affected (and possibly make oneself feel better). This was seen in the $G Q$ article about the Pulse nightclub shooting: "The community's knee-jerk reaction was: "I have to do something" (Flynn, 2016). The definition of community togetherness as a sub-frame needs to change. Togetherness following a shooting is important, but this unity needs to expand to include understanding. Talking with the survivors and considering how their (personal, familial, and friendship) environment(s) shape their emotions following a shooting all affect understanding, thereby extending and expanding on the current recovery and mourning frame. Furthermore, extending "togetherness" beyond the recovery and mourning frame to include emotional resonance allows survivors to validate their feelings instead of hiding them once others start moving on. 


\section{Chapter 5: Discussion and Conclusion}

This research attempted to answer following questions:

Primary research question: What dominant frames emerge from men's and women's magazine coverage of mass shootings and how do they promote a particular problem definition or moral evaluation?

Research question 1a: How do the social issues presented in these magazines (mental illness, identity: gender, sexuality, and masculinity and femininity, stereotypes: privilege, race and sexuality) influence the creation and establishment of the overall frames?

Within the sample set of 24 men's and women's magazine articles, a total of four dominant frames emerged: Individual (internal) blame frames, societal (external) blame frames, profiling the shooter, and recovery and mourning. In addition, within these primary frames, several sub-frames were identified. Within each of the dominant frames, certain problem definitions were promoted or moral evaluations were made. From my observations, only mental illness and masculinity played major roles in the overall construction of the frames.

In the individual (internal) blame frame, several themes emerged: The shooter's mental health issues were not (properly) addressed, his or her identity was challenged, and race and sexuality were sometimes motivations for the shooting. In the case of Elliot Rodger, his parents were aware of his mental health issues, yet they hired a "social counselor," an acquaintance of the family rather than a mental health professional to help him (Junod, 2014). In Steven Kazmierczak's case, his family is also aware of his mental health problems, but unlike Rodger's parents, they get him professional help. However, they don't play close enough attention to realize that he has stopped taking his medication and 
is on a path to destruction (Vann, 2013).

Regarding race, it is important to note once again that the articles did not specifically reference the fact that most the shooters during the selected timeframe were white males. This leads me to wonder if the roles were reversed, and most these shootings were committed by non-white males, would the stories have gone into more detail on their race as a motivation for the shootings? Furthermore, it is important to note that white men also make up a majority of the National Rifle Association. On top of this, the element of male white privilege seems to be at play furthering the societal notion that white males are alphas entitled to power, respect, women, and more. This embedded privilege within the white male subset becomes dangerous when they don't get what they believe they are entitled to - in these cases, it leads to mass shootings. In cases where the male also suffers from a mental illness - as was the case with Rodger — the feelings of rage, worthlessness and suicidal thoughts drive a desire to reassert his dominance by doing something horrific that will in turn garner media attention. The moral evaluation for the blame frame is that the shooting should have been prevented by family and medical professionals.

In the societal (external) blame frame, political and institutional failures such as easy access to firearms, loopholes in gun laws, gun trafficking, and lax security clearance and protocols at military establishments (at bases or recruitment centers) created additional problems with mass shootings. Orlando shooter Omar Mateen legally purchased a firearm by completing short three-day waiting period required under Florida law despite the fact he was twice 
investigated for ties to terror networks (Stone and Arneson, 2016). This loophole is called the "terror gap." But even if Mateen had been denied the ability to purchase a gun, he could have easily trafficked one in which is a problem in several states (Krystal Marie Ball and S.E. Cupp, 2015). The moral evaluation for the political and institutional failures frame is that laws and regulations surrounding gun control and security clearance at military bases should have been stricter. The wording of these laws and the protocols for the base(s) should have been clearer, and perhaps a shooting could have been prevented.

In the profiling the shooter frame, two themes emerged: signs that something was wrong were ignored and shooters who were struggling inwardly — mentally or emotionally — did not get the help they needed; they slipped through the cracks. This was the case with the usually quiet Jason Dalton and clearly unstable Elliot Rodger. Dalton was a sociable family man that according to his neighbors and someone that no one would have predicted doing what he did (Heath, 2016). On the other hand, Rodger was outwardly unstable and even cried out to his family for help by sending them links to disturbing websites and videos (O'Neil, 2014). His attempts were either ignored or brushed off as him being a broody young adult. The moral evaluation for the profiling the shooter frame is people should have been more attuned to behavioral or emotional changes of those close to them; if they were, perhaps these tell-tale signs would have prevented the next mass shooting.

In the recovery and mourning frame, the survivors of mass shootings 
struggled to cope with the invasion of privacy they faced from the media. Umpqua Community College shooting survivor Chloe Quinn detailed how violated she felt after seeing her picture all over the news (Brody, 2016). Community togetherness also played a role in the recovery in mourning frame in that it helped progress the recovery process. However, but the unity was short lived as those who were not directly affected helped then moved on with their lives. The survivors were left to process what happened on their own or group together and build their own sense of community. In the Orlando shooting everyone was desperate to do something to help in the moment, but as time progressed and the survivors started to process what happened and enter the recovery process, many people had moved on (Flynn, 2016). The survivors were forced to lean on one another and create their own community of support as they understood what the other had gone through and knew it might take a lifetime to move on (Wildman and Robbins, 2015).

The moral evaluation for the recovery and mourning frame is reporters and those not directly affected by a mass shooting should have been more sensitive to the feelings of those affected, their privacy, their behavior, etc. If this had happened, perhaps it would have been slightly easier to move on or the mourning period would have been shorter.

There were several nuances between the men's and women's magazines. Men's magazines tended to focus (slightly) more on the graphic details and images of a story in some areas, as opposed to the overall narrative. GQ's Kalamazoo Uber shooter article is an example of this. On the other hand, 
women's magazines focused more on what the survivors felt emotionally and physically in addition to providing some graphic details. One example of this was Cosmopolitan's article on surviving a campus shooting. The women's magazines also had several articles about women coming together after a mass shooting to tell their stories as a group: Glamour's article, We Have to Stop the Violence: How 8 Survivors of Mass Shootings Are Fighting to Make Everyone Safer; Cosmopolitan's article, I Survived a Campus Shooting; Glamour's article How Do You Move on From a Mass Shooting?; and Cosmopolitan's article, The Planned Parenthood Shooting Survivors Finally Speak Out, are just a few examples. GQ and Esquire only had stories where one person was the focus or a specific individual was telling their story and any other quotes were added for context. The magazines didn't waver when it came to framing. All the stories fell under one of the frames, sub-frames, or a combination of frames and sub frames. Additionally, references to the two blame frames appeared multiple times in all the articles. It's important to note these differences not only because they were sometimes less noticeable, but because this research is so - comparing framing in men's and women's magazines as opposed to news magazines, newspapers, TV, or broadcast.

In terms of additional media coverage, previous newspaper and television studies, such as Holody, Park and Zhang's (2013) study, focused more on race when covering mass shootings. Their study involved television and newspaper coverage of mass shootings but did not extend its reach to (men's and women's) magazine coverage. Their study also focused primarily on one shooting — Virginia Tech — as 
opposed to a variety of mass shootings or mass shootings as an epidemic. A different newspaper study focused primarily on the negative stories surrounding mental illness and its relationship to mass shootings (Wahl, 2003). This study revealed that dangerousness was the most common theme in stories related to mental illness and positive stories focusing on recovery were limited. Additionally, this study aimed to examine how frames such as mental illness and social issues like gun control enter the framing of mass shootings, like Metzl and MacLeish's (2014) newspaper study. However, unlike Metzl and MacLeish's study, this research expands on the frames that play a role in the shootings and sought to discover how framing varied between magazine genres. One television news study on mass shootings focused more on the 'gore' factor since crime reports consist of 10-20 percent of all TV news stories. This is because "crime news is relatively cheap and readily accessible," (Chermak, 1994).

This research is important because (magazine) consumers often form their opinions on important issues such as mental illness, mental health reform, gun control policies, etc. based off what they read. Therefore, it is important to understand the variety of information being presented to the public and how the meaning of mass shootings is shaped in public discourse. Ultimately, however dependent an audience might be on media discourse, they actively use it to construct meaning. Research from Swidler (1986, p. 273) suggests thinking of culture "as a 'tool kit' of symbols, stories, rituals, and worldviews, which people may use in varying configurations to solve different kinds of problems." 
How do the social issues presented in these magazines (mental illness, identity: gender, sexuality, and masculinity and femininity, stereotypes: privilege, race and sexuality) influence the creation and establishment of the overall frames?

Coverage frames. The primary coverage frames in these 24 articles were related to the impact of shootings on survivors and those close to them, mental health history and mental health reform, blame and political and institutional failures; and that mass shooting coverage was largely about what was being done - if anything - to lessen or prevent future shootings as well as how community togetherness aids in the recovery and mourning process, if only for a short period of time.

Systemic failures. Many of the articles focused on how the "system" failed these individuals - and society as a whole — by allowing them to continue to be a danger to themselves and others until it was too late. For example, one Cosmopolitan article described how Isla Vista shooter Elliot Rodger's mother was aware of his deteriorating mental health status and anger issues (Junod, 2014). These outbursts of anger at the women were due to the belief they had rejected him. He also viewed himself in a highly narcissistic manner and often referred to himself in YouTube videos as the "supreme gentleman." Likewise, Adam Lanza's mother, Nancy, owned at least a dozen firearms and was aware of her son's mental health issues leading up to the shooting, but she did nothing to curb that access or get her son access to medical or professional help. From these cases, it can be perceived that the parents who failed to act and the women who acted 
— albeit in an undesirable way to the shooter — were part of this "system." It is not surprising in the least that events like these - when people are desperate for answers - the idea that violence and mental health are considered.

The magazines focused largely on these systemic failures. However, there seemed to be more focus on violence, rage and entitlement — falling under the umbrella of masculinity - than on the systems that drove these actions in the first place. This toxic approach to masculinity is linked to the sense of entitlement that drives many mass shooters (like Rodger) to commit their crimes. Because of this, masculinity was found to be central in influencing the creation and establishment of the overall frames, in addition to mental illness. However, the research suggests that growing up around guns and suffering mental illness is not enough to send someone on a shooting spree. Those instances coupled with parental neglect or female rejection are.

This presents another problem. Although this information paints a clearer picture of the person behind the shootings, is it enough to point the finger of blame? It's clear from these articles that parents need to be more involved in their child's emotional and social life, but what if the (hateful) opinions and beliefs held by the child are the same as those held by the parent(s)? That's where the slippery slope begins. It's difficult to recognize a harmful belief or activity — like having access to guns when you or your child has a history of a mental illness especially if it's one the parent holds themselves. That said, it is impossible to lay the entirety of the blame on the parents. Even if a parent is involved, observant, and active in their child's life, it is difficult to see long-term changes and faults in 
their own child. Ultimately the child will make his or her own decisions. Whether those decisions could have been prevented if a parent acted differently in some way is impossible to say.

No matter if a parental figure could have prevented the mass shooting(s) or not, the focus of many of these shootings is not on the parents but rather specific individuals. Interestingly, framing shows that this aspect of violence and aggression are not as prominent in post-shooting coverage. Rather, issues such as mental health awareness, mental health reform, and gun control policies play a larger role in the post-shooting news cycle of coverage.

Blame frames. Rather than blaming these acts of violence and aggression solely on violent behavior, reporters seemed to treat the subject in an extremely realistic fashion. They treated the violence as a symptom of the larger problem — a red flag or sign — that these perpetrators are mentally unstable individuals. Often mental illness goes untreated, warning signs are ignored or slip through the cracks. In fact, mental illness is another key component to the creation and establishment of the overall frames. Individuals who fall under this category are often viewed as more likely to commit these seemingly random acts of violence than those who have received or are currently receiving treatment.

Shooter's Identity. The shooter's identity also heavily contributes to the coverage frames. For example: I observed that the magazines' coverage had a difficult time understanding Sandy Hook Elementary School shooter Adam Lanza's motives when compared to the politically, religiously, or sexual identitybased attacks by Charleston Church shooter Dylann Roof, Sikh temple shooter 
Wade Michael Page, or Pulse nightclub shooter Omar Mateen. While Roof, Page, and Mateen had a history of violence, mental illness, racist beliefs and hatred, or a combination, reporters faced more difficulties determining Lanza's motive(s).

\section{Limitations of the study}

The study drew from both print and online articles that offer varied content from one another. One problem found during the study was that several of the online articles did not retain some of the key properties of the print magazine features that could have contributed to the construction of frames - particularly the position and emphasis of accompanying photographs and display type. Headlines and subheads were also different in some cases for the print and online versions of an article. It was also difficult to determine which articles were specifically categorized as features, as this categorization does not exist within the magazine's websites in the same way it does in the print publications. Ultimately, it was determined that articles longer than 1,000 words in length would qualify as online features. However, the study also drew on information provided from follow-up articles that may have not run in printer or smaller, accompanying stories related to a larger feature story on mass shootings or policy change because of mass shootings. This sort of data triangulation has advantages in "the nature and amount of data generated for interpretation" (Thurmond, 2001).

\section{Reflexivity}

Self-reflexivity involves the researcher analyzing his or her biases and how they may interfere with the study at any time. "When it comes to practice, 
the process of engaging in reflexivity is perilous, full of muddy ambiguity and multiple trails" (Finlay, 2002). With this idea of self-analysis in mind, I as a graduate student and practicing researcher acknowledge that media framing of mass shootings as well as the motives behind those shootings have been of interest for years. Furthermore, my former academic institution, Seattle Pacific University experienced a campus shooting on June 5, 2014 while I was a student there which further piqued my interest in the subject — specifically mental illness, gun control policies and the frames surrounding these events. My opinions on mental health reform and gun control also changed significantly following the shooting.

While writing the analysis and discussion portions of this research, I noticed instances of personal bias that started to come out. These cases were further pointed out by my chair and committee members. It's important to remember that when writing a research paper on a topic that hits close to home, personal opinions can slip out and affect how others interpret the research presented to them. After these instances of bias were pointed out, I did my best to eliminate them, thus providing an impartial study.

\section{Future Research}

This study leaves room for plenty of future research. It would be beneficial to conduct in-depth semi-structured interviews with some of the men and women who are regular consumers of these magazines to determine their opinions of the frames presented in the research. If future research was conducted and included in-depth interviews, the new research could draw conclusions based on real-life 
opinions formed by the experiences of the magazines' readers. Furthermore, focusing more on the human aspect of mass shootings, as opposed to the shooter or their motives could be beneficial. By putting yourself in the survivors' shoes - as a reader or a magazine journalist — mass shooting stories could serve as a healing method as opposed to something that further traumatizes those affected. Humanizing mass shootings could also produce new frames in terms of reporting on these stories and the aftermath of the events. Ex: Adding more context about what is being done to prevent these tragedies as opposed to the moments of silence referenced in several of the articles.

Lawmakers, school officials, police, etc. need to see the effect a mass shooting has on survivors. In turn, they might be more likely to enact or implement changes to current laws (gun control, mental health, background checks) because of the visual, emotional impact of what they witnessed. Visualizing the survivors and their expressions after the shooting further humanizes what happened. Now, there isn't just a name; there's a face to connect with the tragedy. There's a live flesh and blood person to mourn with, to listen to, and to learn from. These people and their vulnerability is just one emotionally compelling reason to try and ensure that this kind of act doesn't happen again by way of mental health reform and policy change. However, the quote also serves as a reminder that there's a fine line between showing impact and exploiting tragedy.

Future research could also improve on this study by including a wider scope in terms of both dates and ranges of publications. For example, Men's 
Health and Women's Health could be included as they are clearly gendered men's and women's health and lifestyle magazines. Marie Claire and Maxim also serve as potential additions for further research. By not only expanding the number of publications the research examines, but also expanding the timeframe to include older and newer issues, researchers could analyze how the magazines' frames have changed over a larger timespan and what those changes represent. However, while it makes sense to study magazines that are not only well-known, but also represent a variety of viewpoints, it might be beneficial to expand the study to smaller magazines and websites.

Additionally, new frames could be added such as space frames: How people responded to the mass shootings immediately following, months later, and years after the events took place. Finally, if possible, it would be interesting to explore if different frames would lead to a better society of a decrease in the number of mass shootings, which could present itself as a new research question. For example: Examining mental health and how it is stigmatized in society and how this obstacle can be overcome through mental health reform or further examination of a shooter's mental health history.

Any research on mass shootings is beneficial, whether it focuses on the cause(s) of these events, or the role these shootings play in our society, from a psychological (mental health and mental health reform) or political (gun control policies) standpoint. As these shootings become more commonplace, the need for further research continues to grow. 


\section{References}

Altheide, D. L. (2009). The Columbine Shootings and the Discourse of Fear. American Behavioral Scientist, 52(10), 1354-1370. doi:10.1177/0002764209332552

Ball, K. M. \& Cupp, S.E. (2015, December 3). The San Bernardino Shooting and 353 Mass Shootings This Year: What Will Stop All the Gun Violence. Glamour. Retrieved March 12, 2017 from http://www.glamour.com/story/the-san-bernardino-shooting-an

Bartz, A. (2015, December 3). Why It's So Surprising That One of the San Bernardino Shooters Was Female. Cosmopolitan. Retrieved February 12, 2017 from http://www.cosmopolitan.com/politics/a50259/what-does-itmean-that-a-san-bernardino-shooter-was-female/

Birkland, T., \& Lawrence, R. (2009, June). Media Framing and Policy Change After Columbine. American Behavioral Scientist, 52(10), 1405-1425. doi:10.1177/0002764209332555

Blair, J. Pete, and Schweit, Katherine W. (2014). A Study of Active Shooter Incidents in the United States Between 2000 and 2013. Texas State University and Federal Bureau of Investigation, U.S. Department of Justice, Washington D.C. 2014.

Brown, P. (1995). Naming and Framing: The Social Construction of Diagnosis and Illness. Journal of Health and Social Behavior, 35, 34-52. doi:10.2307/2626956

Burns, R., \& Crawford, C. (1999, October). School shootings, the media, and public fear: Ingredients for a moral panic. Crime, Law \& Social Change, 32(2), 147-168. doi:10.1023/A:1008338323953

Chermak, S. (1994) "Crime in the News Media: A Refined Understanding of How Crimes Become News" Pp. 95-129 in Media, Process, and the Social Construction of Crime: Studies in Newsmaking Criminology, edited by G. Barak. New York: Garland Publishing.

Chyi, H., \& McCombs, M. (2004). Media Salience and the Process of Framing: Coverage of the Columbine School Shootings. Journalism \& Mass Communication Quarterly, 81(1), 22-35. doi:10.1177/107769900408100103.

Clarke, J. N. (1992). Cancer, Heart Disease, and AIDS: What Do The Media Tell 
Us About These Diseases? Health Communication, 4(2), 105-120. doi:10.1207/s15327027hc0402_2

Entman, R. M. (1993, December). Framing: Toward Clarification of a Fractured Paradigm. Journal of Communication, 43(4), 51-58. doi:10.1111/j.14602466.1993.tb01304.

Finlay, L. (2002). Negotiating the swamp: the opportunity and challenge of reflexivity in research practice. Qualitative Research,2(2), 209-230. doi:10.1177/146879410200200205

Friedman, M., Feller, M., Maloney, M., \& Smith, R. (2016, June 13). These Are the Victims of the Orlando Nightclub Massacre. Cosmopolitan. Retrieved March 15, 2017, from http://www.cosmopolitan.com/lifestyle/news/a59840/orlando-pulsenightclub-shooting-victims/

Gamson, W. A., \& Lasch, K. E. (1983). The political culture of social welfare policy.

Gans, H. J. (1979). Deciding What's News: A Study of CBS Evening News, NBC Nightly News, Newsweek, and Time (25th ed.). Evanston, IL: Northwestern University Press.

Goffman, E. (1974). Frame Analysis An Essay on the Organization of Experience. York, Pennsylvania: The Maple Press.

Gray, H. (1995). Watching race: Television and the struggle for "Blackness." Minneapolis, MN: University of Minnesota Press.

Holody, K. J., Park, S., \& Zhang, X. (2013). Racialization Of The Virginia Tech Shootings. Journalism Studies, 14(4), 568-583. doi:10.1080/1461670X.2012.726499

Ingraham, C. (2016, February 26). We have three different definitions of 'mass shooting,' and we probably need more. Retrieved October 8, 2016, from https://www.washingtonpost.com/news/wonk/wp/2016/02/26/we-havethree-different-definitions-of-mass-shooting-and-we-probably-need-more/

Kessler, R. C., Sonnega, A., Bromet, E., Hughes, M., \& Nelson, C. B. (1995, December). Posttraumatic Stress Disorder in the National Comorbidity Survey. Archives of General Psychiatry, 52, 1048-1060. doi:10.1001/archpsyc.1995.03950240066012'

Kimmel, M. (2008). Profiling school shooters and shooters' schools: The cultural 
contexts of aggrieved entitlement and restorative masculinity. In B. Agger, \& D. Luke (Eds.), There is a gunman on campus: Tragedy and terror at Virginia Tech. Lanham, MD: Rowman and Littlefield.

Kimmel, M. S., \& Mahler, M. (2003). Adolescent masculinity, homophobia, and violence: Random school shootings, 1982-2001. American Behavioral Scientist, 46(10), 1439.

Kwon, K. H., \& Moon, S. (2009, September 23). The bad guy is one of us: Framing comparison between the US and Korean newspapers and blogs about the Virginia Tech shooting. Asian Journal of Communication, 19(3), 270-288. doi:10.1080/01292980903038998

Maguire, B., Weatherby, G., \& Mathers, R. (2002). Network News Coverage of School Shootings. Social Science Journal, 39, 465-470.

Mascia, J. How Redditors Are Changing the Way Media Counts Mass Shootings. (2015, October 08).

McGinty, E. E., Webster, D. W., Jarlenski, M., \& Barry, C. L. (2014). News Media Framing of Serious Mental Illness and Gun Violence in the United States, 1997-2012. American Journal of Public Health, 104(3), 406-413.

McQuail, D. (2000). McQuail's mass communication theory (4th edn.). London: Sage.

Muschert, G., \& Carr, D. (2006). Media Salience and Frame Changing across Events: Coverage of Nine School Shootings, 1997-2001. Journalism \& Mass Communication Quarterly, 83(4), 747-766. doi:10.1177/107769900608300402.

Muschert, G. \& Larkin, R. (2007). "The Columbine High School shootings." In Steven Chermak \& F.Y. Bailey (Eds.), Crimes and trials of the century ( $p$. 253-266). Westport, CT: Praeger.

Norris, F. H. (2002). Disasters in urban context. Journal of Urban Health, 79(3), 308-314.

Norris F.H., Foster J.D., Weisshaar D.L. (2002). The epidemiology of sex differences in PTSD across developmental, societal, and research contexts. In: Kimerling R, Ouimette P, Wolfe J, eds. Gender and PTSD. New York, NY: Guilford Press; 207- 231.

North CS, Nixon S.J., Shariat S., et al. (1999). Psychiatric disorders among survivors of the Oklahoma City bombing. JAMA. 282: 755762. 
Orsillo SM, Raja S, Hammond C. (2002). Gender issues in PTSD with comorbid mental health disorders. In: Kimerling R, Ouimette P, Wolfe J, eds. Gender and PTSD. New York, NY: Guilford Press; 207-231.

Reddit.com Traffic Statistics. Retrieved November 16, 2016, from https://www.similarweb.com/website/reddit.com

Reese, Stephen. (2007). The framing project: A bridging model for media research revisited. Journal of Communication, 57: 148-154. doi:10.1111/j.1460-2466.2006.00334.x

Scheufele, D. A., \& Tewksbury, D. (2007). Framing, Agenda Setting, and Priming: The Evolution of Three Media Effects Models. Journal of Communication, 57(1), 9-20. doi:10.1111/j.1460-2466.2006.00326.x

Schildkraut, J. (2012). Media and massacre: A comparative analysis of the reporting of the 2007 Virginia Tech shootings. Fast Capitalism, 9(1), 1-22. http://www.uta.edu/huma/agger/fastcapitalism/9_1/schildkraut9_1.html.

Schon, D. A., \& Rein, M. (1994). Frame reflection: Toward the resolution of intractable policy controversies. New York: Basic Books.

Schnell, K. C. F. (2001). Assessing the democratic debate: How the news media frame elite policy discourse. Political Communication, 18(2), 183-213.

Surette, R. (1992). Media, crime \& criminal justice, images and realities. Pacific Grove, CA: Brooks/Cole Publishing.

Swidler, A. (1986, April). Culture in Action: Symbols and Strategies. American Sociological Review, 51(2), 273-286. Retrieved October 8, 2016, from http://www.nyu.edu/classes/persell/alntroNSF/Documents/ASRSwidler198 6.pdf

Tankard, James W. (2001). The empirical approach to the study of media framing. In Stephen D. Reese, Oscar H. Gandy, Jr., \& August .E. Grant (Eds.), Framing public life: Perspectives on media and our understanding of the social world (p. 95-106). Mahwah, NJ: Lawrence Erlbaum.

The Hammerskin Nation. (n.d.). Anti-Defamation League. Retrieved January 15, 2017, from

https://www.adl.org/education/resources/profiles/hammerskinnation? xpicked=3\&item $=15$.

Thurmond, V. A. (2001), The Point of Triangulation. Journal of Nursing Scholarship, 33: 253-258. doi:10.1111/j.1547-5069.2001.00253.x 
Wahl, O. (2003). News Media Portrayal of Mental Illness: Implications for Public Policy. American Behavioral Scientist, 46(12), 1594-1600. doi: 10.1177/0002764203254615

Weaver D. H. (2007). Thoughts on Agenda Setting, Framing, and Priming. Journal of Communication. 57, 142-147. doi:10.1111/j.14602466.2006.00333.x

Ziporyn, T. D. (1988). Disease in the popular American press: The case of diphtheria, typhoid fever, and syphilis, 1870-1920. New York: Greenwood Press. 